\title{
Assessing the Potential Benefit of Trade Facilitation: A Global Perspective
}

\author{
by \\ John S. Wilson ${ }^{*}$, Catherine L. Mann ${ }^{+}$and Tsunehiro Otsuki ${ }^{* *}$
}

\begin{abstract}
World Bank Policy Research Working Paper 3224, February 2004
The Policy Research Working Paper Series disseminates the findings of work in progress to encourage the exchange of ideas about development issues. An objective of the series is to get the findings out quickly, even if the presentations are less than fully polished. The papers carry the names of the authors and should be cited accordingly. The findings, interpretations, and conclusions expressed in this paper are entirely those of the authors. They do not necessarily represent the view of the World Bank, its Executive Directors, or the countries they represent. Policy Research Working Papers are available online at http://econ.worldbank.org.
\end{abstract}

\footnotetext{
* Transport Unit and Urban Development Department (TUDTR), World Bank, 1818 H Street, NW, Washington, DC.

${ }^{+}$Institute for International Economics, 1750 Massachusetts Ave NW, Washington DC

** Development Research Group (DECRG), World Bank.

Corresponding email: totsuki@,worldbank.org. The views expressed here are those of the authors and should not be attributed to the World Bank or the Institute for International Economics.
} 


\section{Summary}

The relationships between trade facilitation, trade flows, and capacity building are complex and challenging to assess, both empirically and in implementation. This paper measures and estimates the relationship between trade facilitation and trade flows in manufactured goods in 2000-2001 in global trade, considering four important categories: port efficiency, customs environment, regulatory environment, and service sector infrastructure. A gravity model is employed to estimate this relationship across 75 countries. The results suggest that both imports and exports for a country and for the world will increase with improvements in these trade facilitation measures. The gains from trade facilitation are predicted by using a simulation method, and compared across geographical regions, trade facilitation categories and who is undertaking reforms (domestic or partners). The total gain in trade flow in manufacturing goods from trade facilitation improvements in all the four areas is estimated to be $\$ 377$ billion; all regions gain in imports and exports. Most regions gain more in terms of exports than imports, in large part through increasing exports to the OECD market. The most important ingredient in getting these gains, particularly to the OECD market, is the country's own trade facilitation efforts. 


\section{Introduction}

The relationships between trade facilitation, trade flows, and capacity building are complex and challenging, to assess empirically and in implementation. Even the first step - relating trade facilitation and trade flows - encounters the problem of definition and measurement of trade facilitation. However, as tariffs come down, assessing how other factors affect trade has increasing policy relevance. Once trade facilitation is defined and measured, the challenge is to estimate its effects on trade flows. A country's trade will change not only through its own trade facilitation reforms, but also the reforms of its trading partners. Differences in the relative magnitude of trade facilitation efforts on trade, as calculated by category of trade facilitation effort or group of trading partners, could point to negotiating and capacity building focus. This paper measures and estimates the relationship between trade facilitation and trade flows, considering the relationships from a variety of perspectives. The hope is that the outcome will help inform policy decisions and capacity building choices.

Empirical research on the issue of trade facilitation faces three challenges: defining and measuring trade facilitation; choosing a modeling methodology to estimate the importance of trade facilitation for trade flows; and designing a scenario to estimate the effect of improved trade facilitation on trade flows.

- It is important to define and measure trade facilitation with the objectives in mind of informing policy and aiding capacity building. Accordingly, we consider four aspects of trade facilitation effort: ports, customs, regulations, and e-business (which is a proxy for the service sectors of telecommunications and financial intermediation, which are key for all types of trade). Simply benchmarking a country's condition in these four areas with respect to the global average and best practice yields insights for capacity building and policy attention.

- The modeling methodology is particularly important because it has to account for the fact that both export and import trade flows will be affected by trade facilitation efforts, and that the effect of trade facilitation will differ depending on the trading patterns of the countries being examined. Accordingly, we include trade facilitation measures for countries as importers and as exporters. Investigating the stability of the estimated relationship across directions of trade (north-south, south-south) adds insight on which measures may be most important for addressing capacity building.

- The scenario design needs to account for differences among countries relative to best practice. Accordingly, we consider scenarios where each country improves toward best practice by a country-specific amount.

So as to assist in policy design and capacity building, the presentation of results allows a country to judge the potential outcome of trade facilitation efforts unilaterally, by region, and multilaterally. Since each country is characterized by four unique trade facilitation measures, each of these measures bears a unique relationship to global best, 
and each country has a unique trading pattern, the determination of which trade facilitation effort might yield the greatest increase in trade is unique to each country.

Finally, the juxtaposition in multilateral forums of trade facilitation discussions and tariff negotiations points to the need to assess the relationship between these two approaches as they affect trade flows. In this paper we offer some insights on these issues using a sample of 75 countries.

\section{Overview of Previous Work}

\subsection{Definition of Trade Facilitation}

There is no standard definition of trade facilitation in public policy discourse. In a narrow sense, trade facilitation efforts simply address the logistics of moving goods through ports or more efficiently moving documentation associated with cross-border trade. In recent years, the definition has been broadened to include the environment in which trade transactions take place, transparency and professionalism of customs and regulatory environments, as well as harmonization of standards and conformance to international or regional regulations. These move the focus of trade facilitation efforts "inside the border" to domestic policies and institutional structures where capacity building can play an important role. In addition, the rapid integration of networked information technology into trade means that modern definitions of trade facilitation need to encompass a technological concept as well.

In light of this broadening definition of trade facilitation, our definition of trade facilitation incorporates relatively concrete "border" elements, such as port efficiency and customs administration, and "inside the border" elements, such as domestic regulatory environment and the infrastructure to enable e-business usage.

\subsection{Measuring the Impact of Trade Facilitation}

The empirical literature on trade facilitation is limited; it is outlined in more detail in Wilson, Mann, and Otsuki (2003) (henceforth WMO). Briefly, however, the tendency in work previous to WMO is first, to discuss what researchers would like to measure, but not to find measures or estimate their impact on trade (Maskus, Wilson, and Otsuki (2001), Asia Pacific Foundation of Canada (1999)). Second, some use a single measure of trade facilitation to estimate effects of trade facilitation on trade.

These latter estimates suggest large gains from trade facilitation efforts. A 3 percent reduction in landed costs applied to intra-APEC merchandise trade, as might be obtained by electronic documentation, reduces trade costs by US\$60 billion. ${ }^{1}$ A 1 percent reduction in import prices for the industrial countries and the newly industrializing countries of Korea, Chinese Taipei and Singapore, and a 2 percent reduction for the other developing countries yields an increase in APEC merchandise trade of 3.3 percent - meaning the elasticity of trade facilitation efforts to trade flows is

\footnotetext{
${ }^{1}$ See Paperless Trading: Benefits to APEC (2001), page 18.
} 
greater than $1 .^{2}$ Considering global estimates, a 1 percent reduction in the cost of maritime and air transport services in the developing countries could increase global GDP some US\$7 billion (1997 dollars). If trade facilitation is considered in a broader sense to include an improvement in wholesale and retail trade services, an additional US\$7 billion could be gained by a 1 percent improvement in the productivity of that sector. ${ }^{3}$

Other authors consider more specific categories of trade facilitation effort or a more limited country set. Hertel, Walmsley and Itakura (2001) find that greater standards harmonization for e-business and automating customs procedures between Japan and Singapore increase trade flows in overall between these countries as well as their trade flows with the rest of the world. Hummels (2001) finds that each day saved in shipping time in part due to a faster customs clearance is worth 0.5 percentage point reduction of ad-valorem tariff. Fink, Mattoo, and Neagu (2002a) examines the effect of anticompetitive practices in port services and other transport services on unit shipping cost. Freund and Weinhold (2000) find that a 10 percent increase in the relative number of web hosts in one country would have increased trade flows by one percent in 1998 and 1999. Fink, Mattoo, and Neagu (2002b) find that a 10 percent decrease in the bilateral price of phone calls is associated with an 8 percent increase in bilateral trade. Moenius (2000) finds that bilaterally-shared and country-specific standards on goods trade promotes trade. Otsuki, Wilson, and Sewadeh (2001a, 2001b) find that 10 percent tighter food standards in the European Union would reduce African exports of certain cereals, nuts, and dried foods by a range of 5 to 11 percent, depending on the category.

WMO change these approaches to estimating the effect of trade facilitation on trade flows by constructing four measures of trade facilitation and estimating the independent effects of these four on the trade flows among a broad group of countries in the Asia Pacific region. WMO use cross-country survey data on the business and policy climate in each APEC member to construct numerical measures of trade facilitation for each APEC member for port efficiency, customs environment, regulatory environment and , e-business usage (a proxy for service sector infrastructure important for trade). They find that the elasticity of increased port efficiency of importing countries is larger than the elasticity of improved customs environment or superior service sector infrastructure. A unilaterally applied more stringent regulatory environment will reduce a country's imports. In simulations, they find that for the APEC economies as a group, improving port efficiency, customs environment and service sector infrastructure measures of the below-APEC-average economies half-way up to the APEC average for each trade facilitation measure yields an increase in trade of some 20 percent. Although on average the port efficiency indicator is the most important for trade facilitation, since each country has a unique set of indicators and pattern of trade, more detailed analysis of the simulation results shows that for some members of APEC, a trade facilitation measure other than ports may be the best to target for capacity building to improve that economy's trade.

${ }^{2}$ Assessing APEC Trade Liberalization and Facilitation: 1999 Update, Economic Committee, September 1999 , page11.

${ }^{3}$ See UNCTAD, E-Commerce and Development Report 2001, tables 8-11, page 33-36. 


\section{Data in This Study}

\subsection{Rationale for These Indicators of Trade Facilitation}

The first essential task in the quantitative analysis of trade facilitation is to develop measures of trade facilitation. WMO present four distinct areas of focus that meet policymakers' needs for specificity on how to approach trade facilitation efforts. They are: (1) port efficiency, (2) customs environment, (3) own regulatory environment, and (4) service sector infrastructure.

Port efficiency is designed to measure the quality of infrastructure of maritime and air ports. Customs environment is designed to measure direct customs costs as well as administrative transparency of customs and border crossings. Regulatory environment is designed to measure the economy's approach to regulations. Service sector infrastructure ${ }^{4}$ is designed to measure the extent to which an economy has the necessary domestic infrastructure (such as telecommunications, financial intermediaries, and logistics firms) and is using networked information to improve efficiency and to transform activities to enhance economic activity. ${ }^{5}$

Besides the observation that these categories match areas for policy-maker attention, these trade facilitation measures also match several GATT articles and appear in the list of Singapore issues in the Doha Development Agenda, and therefore have salience for WTO negotiations. The port efficiency measure has been constructed in accordance to GATT article V (freedom of transit). This article says that freedom of movement is to be assured for goods, which should be allowed to move via the most convenient route, should be exempt from customs or transit duties, and should be free from unnecessary delays or restrictions. Customs environment here consists of components that have their basis in the GATT article VIII. GATT article VIII states that in order to minimize impediments to trade due to customs procedures, fees charged by customs officials must be limited to the approximate cost of customs services. Also, there should not be substantial penalties for minor breaches of customs regulations such as clerical errors. Regulatory environment issues are contained in GATT article X which discusses Publication and Administration of Trade Regulations. This article comes from the basic transparency obligation that requires prompt publication of laws and regulations affecting imports and exports so that foreign governments and traders may clearly understand them.

\subsection{Constructing the Measures Used in This Study}

This paper builds on the WMO methodology and categories of trade facilitation. However, because this paper broadens the set of countries for analysis to 75, the crosscountry survey data on business and policy climate that are used to construct the four indicators for each country are somewhat different from the data used to construct the

\footnotetext{
${ }^{4}$ WMO used a different terminology- e-business usage- for this category.

${ }^{5}$ For further discussion of the relationship between domestic infrastructure and e-commerce, see Mann, Eckert, and Knight (2000).
} 
indicators in WMO. Specifically, we drop data sources that have limited country coverage (Clark, Dollar and Micco (2001) and Transparency International), but include Kaufmann, Kraay and Zoido-Lobaton (2002) (henceforth KKZ) which has a wider country coverage. Therefore, we rely on three sources--World Economic Forum Global Competitiveness Report 2001-2002 (henceforth GCR), IMD Lausanne, World Competitiveness Yearbook 2002 (henceforth WCY), and KKZ. See the Appendix for a more complete description of the sources and each of their methodologies for collecting and preparing data about a country.

Because the survey scales of the sources differ, we must put all survey data from the three sources on comparable basis. In contrast to WMO, we index each observation of a raw series (which is an observation representing a country) to the maximum of all the countries' value for the raw series (e.g. global best practice). WMO used the mean of all countries as a benchmark for each of the indexes. We use the maximum as a benchmark since this easily indicates how far a country's performance is from the best practice country whose indexed value is 1.0 .

Two survey data inputs are used to form each of the trade facilitation measures. We use multiple survey inputs into each trade facilitation indicator to avoid depending too heavily on any one survey question or source.

The next step in creating the trade facilitation indictors involves collecting these indexed inputs into the four specific trade facilitation indicators. A simple average of the two indexed inputs is used for transparency of method, and also because there is no specific argument (theoretical or statistical) to choose a different aggregation method. Therefore:

- Port efficiency for each country $J$ is the average of two indexed inputs from GCR:

$\circ$ Port facilities and inland waterways

- Air transport

- Customs environment for each country $J$ is the average of two indexed inputs from GCR:

○ Hidden import barriers

- Irregular extra payments and bribes

- Regulatory environment for each country $J$ is constructed as the average of indexed inputs from WCY and KKZ:

- Transparency of government policy is satisfactory (WCY)

○ Control of Corruption (KKZ)

- Service sector infrastructure for each country $J$ is from GCR:

- Speed and cost of internet access

- Effect of internet on business 
Within each of the trade facilitation categories, the correlation of the inputs that go into the final index are high, but less than one suggesting robustness of the methodology of using more than one survey indicator to construct the indicator. As well, this raises confidence that the indicator is correctly assessing each country on that particular indicator of trade facilitation. Correlation coefficients of the inputs to the indicators are $0.802,0.820,0.696$, and 0.658 for categories of port efficiency, customs environment, regulatory environment and service sector infrastructure, respectively.

Table 1 and Figures 1 to 4 (one for each trade facilitation indicator) report information about these indicators. Table 1 shows, for each input as well as for the trade facilitation indicator, the mean, standard deviation, and minimum value along with countries of best and worst practice. For best practice Singapore and Finland stand out. Worst practice is well distributed among many countries and regions of the world. The figures show the indexed inputs for regional groups of countries for each specific trade facilitation indicator. ${ }^{6}$ Each indexed input is represented by a horizontal bar. The longer the bar extends to the right toward the maximum of 1.0, the higher ranked the region is in the category of trade facilitation. A vertical line is drawn at the average value. If a bar extends beyond the average for the particular trade facilitation measure, that indexed input for that region represents a condition superior to the average for all countries. For example, Figure 1 shows that OECD, Middle East and North Africa (MENA) ${ }^{7}$ and East Asia regions are above the global average in terms of the two indexed inputs for port efficiency.

\subsection{Trade Flows and Other Variables}

We use bilateral trade flow data available at the Commodity and Trade Database (COMTRADE) of the United Nations Statistics Division, for 2000 and 2001. We focus our attention on trade in manufactured goods, defined as commodities in categories 5 to 8 in SITC 1 digit industry except those in category 68 (non-ferrous metals). Our trade flow data aggregate the trade flows over the manufactured goods for a given importer-exporter pair. ${ }^{8}$

Tariff data were derived from the Trade Analysis and Information System (TRAINS) of the United Nations Conference on Trade and Development (UNCTAD). We use the weighted average of applied tariff rates for the manufactured goods in 2000 and 2001 under the above definition where bilateral trade values corresponding each tariff line are used as the weight. The data on gross national p-roduct (GNP) and per capita GNP were derived for years 2000 and 2001 from the World Development Indicators published by the World Bank.

\footnotetext{
${ }^{6}$ These regional indicators use a simple average of the region. An average weighted by trade or GDP would no doubt yield somewhat different results. There is no clear interpretation of alternative weighted averages. Moreover, these regional indexes are not used in estimation.

${ }^{7}$ Data are available only for Egypt, Jordan, and Israel.

${ }^{8}$ Standard International Trade Classification. Revision 1 is used for our definition.
} 


\section{The Econometric Model and Results}

\subsection{An Aside on the Gravity Model}

The gravity model of international trade flows, which we use, is a common approach to modeling bilateral trade flows. It is enjoying a resurgence of interest given its natural kinship with current interests in the relationship between geography and trade. The standard gravity formulation includes various measures of market size (GDP, population, GDP per capita to account for intra-industry trade effects that may be associated with countries of similar incomes but varied tastes), measures of remoteness (distance and adjacency), and measures of kinship (regional trade arrangements, and language/ethnic similarities). To this basic formulation, we will add tariffs as well as the trade facilitation indicators and some additional factors, as described further below.

Despite the empirical success of gravity models to mimic trade patterns, there are serious questions as to the theoretical validity of the gravity model formulation. Some studies attempt to add additional structural elements to the gravity model to better reflect real world observations. These mainly concern the heterogeneity of traded goods in quality and price by origin, and price differentials associated with border and transportation costs. Anderson (1979) develops a gravity model in line with a general equilibrium framework. He incorporates into a gravity model consumers' preferences over goods that are differentiated by region of origin, assuming the constant elasticity of substitution (CES) structure on consumers' preferences. Anderson and von Wincoop (2003) additionally introduce the border costs as premiums on the export prices. Balistreri and Hillberry (2001) extend the results of the Anderson and von Wincoop's gravity model to estimate the transport and border costs separately by distinguishing consumers' and producers' price indices.

\subsection{Our Gravity Model Specification}

Using a standard gravity model as reviewed above, the basic structure of our specific gravity equation is the following:

$$
\begin{aligned}
& \ln \left(V_{J I}^{t}\right)=b_{1} \ln \left(100+\text { TARIFF }_{J I}^{t}\right)+b_{2} \ln P E_{J}+b_{3} \ln R E_{J}+b_{4} \ln S I_{J}+b_{5} \ln P E_{I}+b_{6} \ln C E_{I}+ \\
& b_{7} \ln R E I_{I}+b_{8} \ln S I_{I}+b_{9} \ln \left(G N P_{I}^{t}\right)+b_{10} \ln \left(G N P_{J}^{t}\right)+b_{11} \ln \left(G N P P C_{I}^{t}\right)+b_{12} \ln \left(G N P P C_{J}^{t}\right)+ \\
& b_{13} \ln \left(D I S T_{I J}\right)+b_{14} D_{A D J}+b_{15} D_{A S E A N}+b_{16} D_{N A F T A}+b_{17} D_{L A I A}+b_{18} D_{A U N Z}+b_{19} \\
& D_{M E R C O S U R}+b_{20} D_{E U}+b_{21} D_{E N G}+b_{22} D_{F R C}+b_{23} D_{S P N}+b_{24} D_{A R B}+b_{25} D_{C H N}+b_{26} D_{G M N} \\
& +b_{27} D_{P O R}+b_{28} D_{R U S}+b_{29} D_{2000}+\varepsilon_{J I}{ }^{t}
\end{aligned}
$$


where $I$ and $J$ stand for the importer and exporter respectively, and $t$ denotes trading years $(t=2000,2001)$. Parameter $b$ 's are coefficients. The term $\varepsilon_{J I}{ }^{t}$ is the error term, assumed to be normally distributed with mean zero. The value of manufactures exports from country $J$ to $I$ is denoted as $V_{J I}$ (so exporter to importer). The term $T A R I F F_{J I}$ denotes applied tariff rate in the percent ad valorem term that is specific to the trading partners $I$ and $J$ and year $t$. The inclusion of the tariff variable is useful for reducing omitted variable biases. It is particularly important for some nations since unlike the EU whose tariff policies are harmonized, applied tariff rates generally vary across most other countries and possibly across their exporting partners.

The terms $P E_{J}, R E_{J}$ and $S I_{J}$ denote exporting country $J$ 's indicators of port efficiency, regulatory environment, and service sector infrastructure. Similarly, $P E_{I}, R E_{I}$ and $S I_{I}$ stand for the same trade facilitation measures in the importing country. For the importing country we include one additional measure i.e. "customs environment" or $C E_{I}$. We use "customs environment" only for the importers since in bilateral trade customs is more relevant as a factor affecting imports than exports.

This set of trade facilitation variables is different than in WMO. There, we included only $P E_{I}, R E_{I}, S I_{I}$, and $C E_{I}$. That is, for country $I$ we considered only the effect on imports of unilateral trade facilitation. Country $I$ 's exports improved indirectly when its trading partners improved their trade facilitation efforts. In this formulation, we take explicit account of the fact that country $J$ 's exports (as well as its imports) will improve through its own trade facilitation efforts.

The term GNP denotes gross national product and GNPPC denotes per capita GNP, where both are expressed in 1995 US dollar terms. Geographical distance between capital cities $I$ and $J$ is denoted as $D I S T_{I J}$. Dummy variables are included to capture the effect of preferential trade arrangements, language similarity and adjacency. The trade arrangements dummies include NAFTA $\left(D_{N A F T A}\right)$, ASEAN $\left(D_{A S E A N}\right)$, LAIA $\left(D_{L A I A}\right)$, AUNZ $\left(D_{A U N Z}\right), M E R C O S U R\left(D_{M E R C O S U R}\right)$ and EU $\left(D_{E U}\right)$. The language dummies include English $\left(D_{E N G}\right), \operatorname{French}\left(D_{F R C}\right), \operatorname{Spanish}\left(D_{S P N}\right), \operatorname{Arabic}\left(D_{A R B}\right)$, Chinese $\left(D_{C H N}\right)$, $\operatorname{German}\left(D_{G M N}\right)$, Portuguese $\left(D_{P O R}\right)$ and Russian $\left(D_{R U S}\right)$. The adjacency dummy $D_{A D J}$ takes the value of one if country $I$ is adjacent to country $J$ and zero otherwise. Additionally a dummy for year 2000 is included in the model to control for time-specific shocks.

Table 2 shows the simple correlations among the included variables. All four trade facilitation variables are rather highly correlated with each other and rather highly correlated with per capita income of the importer. This is to be expected, first because the trade facilitation indicators are different facets of overall trade facilitation, and second because some of the elements of trade facilitation (administrative transparency, available resources to build quality ports, and so on) are more prevalent in higher income economies.

These relatively high correlations between trade facilitation and income and the use of a single-year observation for the construction of the trade-facilitation indicators in 
cross-section regression analysis points to the potentially ambiguous causal relationship between trade facilitation and trade. We cannot exclude the possibility that greater bilateral trade will lead to higher values of trade facilitation measures rather than the postulated reverse relationship as estimated. Port efficiency, customs environment and service sector infrastructure may induce reforms that improve with a country's import and export flows and the estimated coefficients for these variables would be biased upwards if this endogeneity is present.

A logical approach to the endogeneity problem is (1) to employ instrumental variables for the trade facilitation variables so the error term does not correlate with trade facilitation measures, and/or (2) to extend the trade facilitation data to a multiple year series and to use time-lagged measures of trade facilitation as explanatory variables. Good instruments should be sufficiently exogenous to decision makers or pre-determined, and should uniquely capture the characteristics of each trade facilitation indicator. Given the very large number of countries, finding good instruments is difficult, and data are lacking. We have already used such data exhaustively as inputs to form our trade facilitation indicators. The implication of the use of time-lagged measures was investigated in more depth in WMO using the smaller and more data rich APEC sample, yielding weak evidence that endogeneity was not too large an issue.

Further methodological issue arise from not having time-varying trade facilitation indicators. We cannot use a fixed effects model to isolate country specific effects that are correlated but not specific to trade facilitation. Whereas WMO used a fixed-effects model to account for the variation across exporting countries, here the use of country's trade facilitation measures as an exporter will make it impossible to use fixed-effects for exporting countries. The time-varying gravity variables and the dummy variables will absorb variation other than that caused by differences in trade facilitation such that the trade facilitation variables appropriately capture the country specific effect associated only with trade facilitation. Although, we re-open the endogeneity box with this rationale.

In the end, our estimation can only be improved when panel data with a sufficiently long time series in trade facilitation variables become available, which would allow direct attention to endogeneity and application of fixed-effect modeling.

\subsection{Regression Results}

The approach used here, which constructs a set of distinct trade facilitation indicators and deploys them in a gravity model of trade, is generally successful. Table 3 displays regression results. The first column includes the estimated coefficients and standard errors for the model under the specification in Equation (1). The second column includes those for the specification with aggregate FTA and language dummies (i.e. membership of any FTA, or any common language). The model was run using an ordinary least squares (OLS). The coefficients for the four trade facilitation measures are statistically significant and the estimated coefficients differ for the different trade facilitation indicators. From a policy perspective, these differences in estimated elasticities of trade flows with respect to trade facilitation indicator implies that different 
approaches to trade facilitation will differentially affect trade of individual countries and of all countries in the sample as a whole. The estimates are robust to the choice of dummy for language and regional arrangement.

Before considering the trade facilitation indicators, it is worthwhile to consider tariffs. Higher tariffs have a significant and the expected negative effect (with -1.2 coefficient) on trade. The coefficient on tariffs is similar to that of distance. In ad valorem terms, the elasticity of tariff is -1.1 at the global average level of tariff rates - i.e. $1 \%$ reduction in ad valorem tariff from the global average (from $8.5 \%$ to $7.5 \%$ ) will increase the trade flow by $1.1 \%$ and a $1 \%$ reduction in distance ( 80 kilometers from the global average) would yield a $1.3 \%$ increase in trade flow. These figures are useful benchmarks against which to compare the coefficients on the trade facilitation indicators.

Port efficiency of both the importer and the exporter is positively associated with trade; that is, an improvement in the indicator toward best practice is associated with an increase in trade flows. Comparing the effect of port efficiency on imports vs. exports, we note that the coefficient is higher for exporters than importer, which implies that global trade flows get a bigger boost when the exporters' port efficiency improves. So for countries and regions that are well below the global best practice, such as Bolivia and Slovak Republic (from Table 1) there is great potential for improvement in terms of port efficiency. Moreover, the range of performance on this measure of trade facilitation is the largest among the trade facilitation indicators (again see Table 1). So, the opportunities for increased trade from improvements in this measure of trade facilitation could be quite large.

Customs environment also has a significantly positive effect on trade of the importing country with an elasticity of 0.47 , which is smaller than that for tariffs. Although the two metrics are different (ad valorem for tariffs and survey indicator for customs), the sign and size of elasticity present support for the attention to this as a Singapore issue. Trade facilitation is a possible avenue for reducing the cost of imports through customs improvements even as tariffs remain where they are.

Improving the regulatory environment of the importer and exporter has a positive and significant association with trade with coefficients of 0.28 and 0.62 , respectively. As with ports, the magnitude of the coefficient is larger for the exporter than for the importer. The sign of the coefficient for regulatory environment of importer is reversed from that in WMO. In contrast that paper, the survey inputs used to construct regulatory environment indicator in this analysis are more unambiguously trade-promoting. Regulatory transparency and control of corruption (the two inputs) reduce unnecessary information costs of trading and reduce barriers to private business.

Improving indicators of service sector infrastructure are positive and significantly associated with trade among the studied countries. Similar to port efficiency and regulatory environment, service sector infrastructure have a more significant positive effect on the exporters than for importers. The elasticity of the exporters' service sector infrastructure is the highest among all trade facilitation measures (1.94). This high 
elasticity should come as no surprise since the role of the services-sectors in trade facilitation is important. ${ }^{9}$

It is notable that for all the trade facilitation indicators that are paired (that is, are estimated for both exporters and importers), the coefficient for exporters exceeds that for importers. There are several reasons why this might be the case. First, in the sample of countries, there are 30 developed countries (North) and 45 developing countries (South). Thus, the sample is weighted toward developing countries where the elasticity of improvement in trade facilitation indicators is likely to be higher than for the developed countries whose trade facilitation indicators are already high. Second, the pattern of trade in general is South-North (even if the value of trade North-North is larger). So, the estimated coefficients would tend to pick up the higher elasticity of trade from the South to the North.

To further investigate this issue, as well as to shed light on the potential for capacity building in the area of trade facilitation in the south, we examined the gravity model using several sub-sets of the 75 countries bilateral trade. Specifically, we reestimated the gravity model on south-to-north trade and on south-to-south trade. Table 4 presents the results for the trade facilitation indicators for two sub-panels. Also repeated in the table for convenience are the values of the coefficients from the full panel.

Comparing across the three panels, several points emerge. In the South-to-North panel, many of the variables added to the gravity model for the North (as importer) are not significant -- tariffs, port efficiency, the customs environment, and (nearly) the regulatory environment. The lack of significance on tariffs suggests that tariffs are not a major impediment to South-to-North trade. The fact that the trade facilitation indicators are nearer to global best in the North means that the other variables in the gravity model (such as GDP) dominate in estimation. On the other hand, the service sector infrastructure indicator has a higher coefficient than in the full sample for both importer and exporter, corroborating work cited earlier on the benefits of more Webhosts and lower telecommunications costs for trade. The high coefficient on regulatory environment in the exporting country (South) would support a focus on capacity building in this area in the South.

Second, compare the South-to-South panel with the other two samples. Tariffs are once again significant, suggesting that south-to-south trade is more affected by tariffs than is south-to-north trade. Regulatory environment appears to be very important for both directions of trade. Looking at all the indicators, the coefficient estimated on the exporter is larger than the full sample and larger than for the importer in the restricted sample, suggesting that trade facilitation efforts and capacity building could play a complementary role in export promotion in the south.

\footnotetext{
${ }^{9}$ Other research investigates the relative magnitude of service sector liberalization compared to manufactures and agricultural liberalization in the context of the Uruguay round and the Doha Agenda. Several researchers conclude that liberalization of services trade would yield at least as large an increase in GDP than does liberalization of manufactures trade, and much larger than liberalization of agriculture trade. See the discussion and sources in Mann, Rosen and APEC (2001, 2002), pages 33-35.
} 
Finally, given the juxtaposition in the Doha Agenda of tariff negotiations and Singapore trade facilitation issues, it is interesting to apply the regression results to the question of tariffs vs. trade facilitation. The data used in the estimation indicates an average 8.5 percent tariff rate. Figure 5 suggests that a complete tariff elimination would be associated with an increase in trade flow equivalent to a $15.6 \%$ (or $5.2 \%$ ) improvement in port efficiency by importer (or exporter) or a $10.2 \%$ improvement in customs environment by the importer or an increase in indicator of service sector infrastructure by $6.6 \%$ (importer) or $2.5 \%$ (exporter). In terms of regulatory environment the same trade gains from a complete tariff cut is equivalent to $17.0 \%(7.8 \%)$ improvement of regulatory environment by importer (exporter).

\subsection{Implications of Geographical Characteristics}

Geographical characteristics such as being landlocked or an island can affect trade. Frankel and Rose (2000) included dummy variables for those geographical characteristics to allow for the intercept term to vary accordingly. We additionally allow for the coefficient for trade facilitation indicators to vary according to those characteristics. Our particular interest is whether ports play more important role in the import and export of landlocked countries, or whether ports play a less important role for island countries. Ports may play a less important role in trade between countries that share land borders. We perform this analysis by additionally introducing cross-product terms between the port efficiency indicators and these geographical characteristics based on the main regression model.

Landlocked, island, and adjacency variables are used here to differentiate the effect of port efficiency. Table 5 indicates the results for varied specifications. In the first three columns one characteristic is considered at a time. In the fourth column landlockedness and island are jointly considered as these characteristics are mutually exclusive. The last column allow for the coefficients for port efficiency to vary with respect to all the three characteristics. Consider first geographical adjacency. As expected, for countries that share land borders, ports are less important than for countries that do not. Interpreting the estimates for landlocked and island is more difficult. For landlocked countries, the importance of ports are as important for both import and export as in non-landlocked countries since the product terms are insignificant. Landlocked countries are disadvantaged in maritime transport but may have developed ground and air transport infrastructure and our port efficiency indicator is a combination of both types of ports. For island countries, it appears that ports are more important for their import and less important for their export compared to non-island countries. This result is difficult to interpret, but is consistent with some research that finds that small island economies are disadvantaged in export trade because they cannot offer a scale of production sufficiently large to compete in international markets or be part of an international value chain in production (Winters, 2004).

\subsection{Robustness of the OLS Estimators}

OLS estimation imposes the assumption that the error term is identically distributed. This assumption often is inappropriate for grouped data where the error term 
is heterosckedastic. Robustness of the OLS estimated standard error of the coefficients is examined by using heterosckedasticity-robust variance. The second column of Table 6 reports the Huber/White sandwich estimator of variance which is used without specifying a cluster (group) of the sample (see White (1980) for the procedure). In the third and fourth column a cluster is formed with respect to importer and exporter, respectively. As an alternative approach, we performed weighted least squares (WLS) by correcting the error term for heterosckedasticity by using the estimated variance for importer (the fifth column) or exporter (the sixth column). These results are compared with the main result displayed in the first column. Standard error are acceptably robust across those specifications. The significance of the key variables generally remain. The WLS coefficients are also similar to the OLS ones while a few coefficients turn insignificant.

\section{Potential Benefits from Trade Facilitation: Simulation Results}

\subsection{Simulation Design and Aggregate Results}

The gravity model approach allows us to consider how much trade among the 75 countries might be increased under various scenarios of improved trade facilitation and/or tariff reduction. We will examine scenarios that focus on improved port efficiency, improved customs environment, improved service sector infrastructure, and regulatory environment. Our objective in the simulations is to help inform policymakers on which specific trade facilitation initiatives might have the greatest potential to increase trade and economic well-being.

We follow the simulation strategy presented in $\mathrm{WMO}$, which uses a formula to design a unique program of reform for each country in the sample. The formula brings the below-average countries in the group half-way to the average for the entire set of countries. We focus on the below-average country on the grounds that donor attention and capacity building efforts should be extended to this group. It is not that the country with the best practice should not try to do better; it is just that limited multilateral resources are not best utilized that way.

We choose an improvement of half-way to the average because there are limited development resources and improvements take time. Dramatic improvements are possible, but it is not realistic to presume a scenario whereby all countries in the sample are assumed to achieve best practice as measured by the nation with the highest score on a particular measure of trade facilitation. ${ }^{10}$ Since each economy has a specific value for each trade facilitation indicator, each country that is below-average on that indicator will improve by a different amount so as to get half-way to average. Our simulation approach acknowledges the differential potential for improvement revealed by Table 1. This approach contrasts with the here-to-fore standard approach to simulation design where all

\footnotetext{
${ }^{10}$ Moreover, it is the case that in the course of the simulation, the 'average' target will rise, and we do not take account of this endogeneity. By restricting the improvement to half-way to average, we limit to some degree these second round effects.
} 
countries improve trade facilitation measures by a given percentage, such as when trade costs are 'shocked' by, say, 1 percent in a CGE model.

Therefore, the countries for which we will simulate an improvement in trade facilitation will differ by the trade facilitation indicator. However, because trade facilitation links exporters and importers, all economies enjoy an increase in trade among each other even when only some have an improvement in their trade facilitation indicator. Having the coefficients for both importer's and exporter's trade facilitation measures enables us to simulate the change in trade flow from different perspectives: the country itself and the group as a whole. Figure 6 shows the various pieces of the simulation.

From the standpoint of a specific country, improvement, say, in port efficiency should increase both its own imports and exports. The same can be expected for regulatory environment, and service sector infrastructure, as well as customs on the import side. But, a country will export more not only from its own reforms, but also because of reforms undertaken by its trading partners as importers. Thus export gains are the sum of the simulated effect on exports of unilateral reform and of import reforms undertaken by the country's trading partners. On the import side, a country's imports increase first on account of its unilateral import reforms, and secondarily on account of the reforms undertaken by its trading partners as exporters. Examining the relative gains to trade from unilateral reforms as compared to partner's reforms, and on exports vs. imports, and across trade facilitation indicators offers three dimensions of potential insight to policymakers, donors, and the private sector.

Table 7 summarizes the results for the simulations and presents the results for the 75 countries as a whole. In total, the collection of simulations on the four trade facilitation indicators yields an increase in trade among the 75 countries worth about $\$ 377$ billion, representing an increase of about 9.7 percent in total trade among these countries. About $\$ 107$ billion of the total gain comes from the improvement in port efficiency and about $\$ 33$ billion emanates from the improvement in customs environment. The gain from the improvement in regulatory environment is $\$ 83$ billion. The largest gain comes from the improvement in service sector infrastructure $(\$ 154$ billion), which is consistent with the broad concept of services infrastructure that this variable is designed to capture.

Table 8 summarizes the change in trade flow by region, by trade facilitation indicators, and by own vs. trading partners' reforms. All this detail can be combined in several ways to give different perspectives on which regions gain the most and why. One cut, exports and imports by region and by trade facilitation indicator, is shown in Figures

7 and 8. Figure 9 show increases in exports from domestic and partner reforms by region and by trade facilitation indicator.

\subsection{Exports and Imports by Region}

The first perspective on the detail is which region gains the most from what kinds of trade facilitation improvement and as an exporter or importer, and whether through 
own or trading partner reforms (as defined in Figure 6). To summarize: In all of these scenarios, the gains from own reforms are much larger, whether as importer or exporter, and the gains as an exporter from own reforms are dramatic. With respect to regions, the largest gainers (in percentage terms) are generally South Asia and Eastern Europe and Central Asia, with Latin American and Caribbean not far behind in terms of potential increases. In contrast, and on account of their relatively lower integration in global trade, Middle East and North Africa and Sub-Saharan Africa do not see much of improvement in their trade experience, either as exporters or importers. The results for Middle East and North Africa and for Sub-Saharan Africa must be viewed with caution as the number of countries with data from these two regions is quite limited. ${ }^{11}$

Considering port efficiency, South Asia gains the most as an exporter (12.1\% increase in trade) followed by East Europe and Central Asia (ECA) (9.5\%). The bulk of South Asia gains come from increased exports due to its own improvements $(11.5 \%)$ as opposed to only $0.4 \%$ export gain due to its importing partners' improvement in port efficiency. South Asia's percentage gain is the highest because the region's average port efficiency is the lowest of all the regions. The "half-way to the average" scenario will consequently lead to a significant improvement in port efficiency in South Asia, which will have a large export promotion effect in the region. An examination of the detail from the simulation finds that in the South Asia region, Bangladesh accrues the highest percentage gain $(32.5 \%)$ whereas India has the maximum gain in dollar amount $(\$ 2.3$ billion). A similar pattern occurs in ECA region, with the export gains from its own improvements at $8.7 \%$ versus only $0.8 \%$ increase in exports due to improvement in ports by its importing partners. In the ECA region the highest export gain is attained by Hungary in the amount of $\$ 3.0$ billion (13.4\% change) and Slovak Republic gains the most in terms of percentage ( $28.8 \%$ or $\$ 2.4$ billion gain).

Examining the importer's side (as defined in Figure 6), regional variation in trade gains in percentage is much smaller for imports than exports. Four out of the seven regions will have an increase of more than 4 percent. The ECA obtains the highest import gain (4.9\%) followed by South Asia (4.5\%). ECA has an increase in imports of $3.1 \%$ from improving its own ports, and an additional $1.8 \%$ increase in imports from its exporting partners' improvement in their port efficiency. For South Asia these percentages are slightly lower: the gains from the partners improvement $(1.4 \%)$ is less than from own improvement (3.1\%). As an example of the country detail from these simulations, in ECA the largest increase in imports from own and partners' reforms turns out to be Hungary and Slovak Republic. Hungary in terms of dollar amount $(\$ 1.5$ billion) and Slovak Republic in terms of percentage (12.3\%). In South Asia, India obtains the largest import gain in dollar amount ( $\$ 0.79$ billion) and Sri Lanka attains the maximum percentage gain $(5.7 \%)$. Thus, improvement in port efficiency is found to provide a country a dual benefit by promoting both imports and exports.

\footnotetext{
${ }^{11}$ The countries from MENA are Egypt, Jordan, and Israel. For SSA, data are available only for Mauritius, Nigeria, and South Africa.
} 
Considering the customs environment, all the regions increase exports from the improvements in customs of the trading partners. This indicator is a good place to show the value of examining the simulation results from the standpoint of exporters or importers and at both regional and country detail. In principle, as exporters, countries gain when their partner's engage in reforms. But, the simulations suggest that the increase in trade coming from the improvement in the country's own customs environment exceeds the increase in trade when the improvement in customs is by the exporters. At least this is true when looking at the regions. Careful analysis of the country detail (where the individual nature of a country's trading pattern is crucial for the simulations) could find a more nuanced result.

For example, as exporters, somewhat larger gains are enjoyed by Latin America and the Caribbean (LAC) and Eastern Europe and Central Asia (ECA), where both regions increase exports by $0.9 \%$. In terms of country detail, in the ECA region Russia gains the most with an amount of $\$ 0.37$ billion $(2.2 \%)$ whereas Ukraine would have the highest percentage gain (4.5\%). In the LAC region Brazil has the highest amount of export gain with $\$ 0.53$ billion export gain whereas Panama would enjoy the highest export gain in term of percentage increase $(5.1 \%)$.

As importers, the increase in trade from own reforms as importers is more than double that for partner's reforms. South Asia accrues the highest percentage gain $(5.8 \%)$. India gains in the amount of $\$ 0.98$ billion (5.4\%) and Sri Lanka gains by $16.9 \%$ with the amount of $\$ 0.25$ billion. In South Asia only India and Sri Lanka turn out to be gainers while no data are available for Bangladesh.

Considering service sector infrastructure, the regional pattern is similar to that of ports, as is the source of the distribution of the gains. From the standpoint as exporter, South Asia gains the most (20.0\%), with the largest export gain by percentage accrued by Bangladesh $(30.6 \%)$ and India gets the maximum gain in dollar amount $(\$ 5.4$ billion of exports. East Europe and Central Asia obtains 13.5\% export gain from improvement in service sector infrastructure half-way up to the average. In the ECA region the largest export gain goes to Russia ( $\$ 6.3$ billion or 37\%) from the improvement of service sector infrastructure. As in the case of ports, the lion's share of the gain comes from country's own improvements, rather than improvements by their trading partners. South Asia gains $0.7 \%$ from the improvement of service sector infrastructure by its trading partners whereas from its own improvement of service sector infrastructure the export gain for South Asia is $19.2 \%$.

If we look at the importers' experience, we find the same picture. South Asia gaining the most as importers (9.3\%) followed by East Europe and Central Asia (ECA) (7.7\%). Again in both regions gains are realized from improvement in service sector infrastructure in trading partners but relatively more imports arrive as a consequence of own improvements. In South Asia, India gains the most as importer ( $\$ 1.7$ billion or $9.6 \%$ ). In the ECA region, Russia has the highest import gain ( $\$ 3.2$ billion or $16.9 \%)$. 
Finally, considering the regulatory environment there is some change in the regional pattern, but not in the source of the gains. Examining first the perspective as exporters, an improved regulatory environment leads to a $7.4 \%$ and $6.1 \%$ export gains for South Asia and LAC, respectively, India contributes the most to the South Asia's gains ( $\$ 2.4$ billion) and Mexico contributes most to LAC's gains (\$2.9 billion). Just as for the other trade facilitation measures, however, the source of the exports gain is predominantly on account of improvements in the exporter's own regulatory environment, rather than a change in the environment of its trading partners.

In the experience of importers, South Asia is the largest gainer in percentage $(4.8 \%)$, followed by the ECA region (4.0\%). In South Asia, India is the largest gainer in the amount and percentage ( $\$ 0.93$ billion $(5.2 \%)$ ). In the ECA region, Turkey is the largest gainer in the amount- $\$ 1.7$ billion (6\%), while Russia gains the largest in the percentage $(6.5 \%)$. As before, the source of the gains comes from own reforms, although the differences are less dramatic. For example, in the case of South Asia, 3.3\% of the gain comes from own reforms and $1.5 \%$ from reforms by trading partners.

The simulation result of the regulatory environment scenario is particularly sensitive due to the large positive coefficient of trade flow with respect to exporter's regulatory environment. The simulation result therefore should be viewed with care.

In overall, from improvement in all trade facilitation measures the highest export gain is attained by South Asia (40.3\%) followed by the ECA region (30.0\%). High gains for South Asia emanates from high export gains due to improvement in port efficiency, and service sector infrastructure. Likewise, the ECA region gains in its exports mainly from reforms in port efficiency and service sector infrastructure. In both cases, the gains come principally on account of their own improvements, rather than the improvements by trading partners. In the South Asia region, India has the highest dollar amount gain ( $\$ 10.4$ billion) and Bangladesh obtains the maximum percentage gain $(68.3 \%)$. In the LAC region, Mexico accrues an export gain in the amount of $\$ 17.3$ billion i.e. the highest in the region and Paraguay realizes a gain of 74.8\%. Mexico and Paraguay's high gains again come from the improvement in ports and service sector infrastructure.

Looking globally, the highest export gain among all the countries due to the combined improvement of all trade facilitation measures is attained by China and it is in the amount of \$120.7 billion. However, the East Asia region (which includes China) does not stand out in terms of export gains since the other countries in that region do not enjoy large export gains because many of the East Asian countries rank rather highly in terms of the trade facilitation indicators already and therefore are not "reforming" very much in these simulations.

In the global picture as importers, South Asia is the biggest gainer (24.4\%) followed by the ECA region (19.8\%). In South Asia region, India gains the most, accruing $\$ 4.4$ billion or $24.5 \%$. India gains in large amount as importer due the improvement in all the trade facilitation measures. In the ECA region, the big winner is Russia gaining a high amount from improvement in service sector infrastructure. 
Finally, it is worthwhile to mention the results for the OECD countries, since they further emphasize the importance of the reforms by the developing countries. The simulations show that the OECD countries increase their imports when the developing countries improve their trade facilitation measures. Whereas the percentage increase in OECD trade as an importer (at 6.9\%) is not particularly dramatic among regional groups, because the level of OECD trade is much larger than any other regional group's trade (at \$2761 billion it represents about three-quarter of the trade in the sample) the dollar value of gains is huge. It is worthwhile for developing countries to invest in their own trade facilitation because the increase in developing country exports will occur through the increased ability to export to the OECD market. The export gains will particularly accrue to the countries which have a drastic reform and those which are net exporters of manufacturing goods.

Does this observation regarding the magnitude of the OECD market mean that South-to-South trade facilitation efforts or regional integration efforts should be abandoned? No. The South-to-South sample discussed earlier shows the importance of improvements in trade facilitation efforts in the south, and suggests that the elasticity of trade facilitation efforts South-to-South could be quite large.

\subsection{Domestic and Partner Improvements}

The relative importance of own reforms is further confirmed by Figure 9. The figure illustrates the simulated change in the sum of imports and exports by region from domestic reforms (left panel) and partners' reform (right panel) in trade facilitation. Comparing across trade facilitation areas, the relative importance of domestic trade facilitation measures differs significantly. The largest increase in trade come from service sector infrastructure and port efficiency. However, these domestic reforms are consistent with the benefits to come from partner's reforms. So, the priority areas for domestic reform within an individual region are the same as those in the scenario of global or collective movement to raise capacity. This has relevance from the standpoint of consistency between objectives of the Doha Agenda and other regional or bilateral negotiations. Finally, this figure also indicates that the gains to developing countries will be much greater than those to the (high-income) OECD countries, because the developed countries in the OECD region are collectively much closer to best practice across all the indicators examined.

Importantly from the standpoint of balance of payments concerns, for most developing countries domestic reforms will yield more exports than imports -- with a significant part of the gains resulting from the increased access to OECD markets. This focus on domestic reforms is somewhat different from the 'request-offer' procedure common in trade negotiations. As the exceptions, Africa and Middle East regions will have relatively small export gains compared to import gains - implying that they do not benefit from the increased access to OECD markets as much. The results suggest that trade facilitation reform should be implemented with particular care in these regions 
when the countries' major objective of the reform is export promotion and there are balance-of-payments concerns.

Finally, in considering the specific nature of capacity building, it is critical go to the country detail. The panels of Figure 10 show, for example, that Guatemala has a great potential for trade gains from its domestic reform in service sector infrastructure. In contrast, for Indonesia, the gains from regulatory reform dominate those associated with the enhancement of service sector infrastructure. Finally, in Nigeria, the reform in its customs system could have the most valuable outcome. Across all the countries considered, domestic reform will have much larger impact on total trade (imports plus exports).

\section{Conclusions and Approach to Capacity Building Design}

The analysis in this paper builds on the method developed in Wilson, Mann and Otsuki (2003). Four indicators of trade facilitation are developed: port efficiency, customs environment, regulatory environment, and e-commerce use by business (as a proxy for service sector infrastructure). These indicators are implemented in a gravity model of trade. Simulations are designed that take account of the differential character of trade facilitation in each country as measured by each of the four categories. Using this set of indicators, modeling approach, and simulation design offers policymakers more information about what type of trade facilitation efforts might provide the largest gains in terms of increasing trade flow.

The improvements to this paper include broadening the country set to 75 countries. In addition, a better measure of regulatory environment was constructed that is less ambiguous in interpretation of its impact on trade.

A particularly crucial improvement in this paper is to consider the effect on bilateral trade flow of trade facilitation reform both from the standpoint of the reforming country's exports and its imports. In the earlier paper, a country gained in exports on account of the improvements to its trading partner's trade facilitation efforts. In this new specification, a country can increase its exports unilaterally through trade facilitation efforts. This will provide information that is useful if a country looks to trade facilitation reforms as a strategy of export promotion.

The total gain in trade flow in manufacturing goods from trade facilitation improvements in all four areas is estimated to be $\$ 377$ billion; all regions gain in imports and exports. Most regions gain more in terms of exports than imports in large part through increasing exports to the OECD market. The most important ingredient in getting these gains, particularly to the OECD market, is the country's own trade facilitation efforts. In terms of regional analysis, South Asia has the greatest potential for both export and import growth, with export gains greater than import gains. In contrast countries in Africa and the Middle East have relatively small export gains compared to import gains because they are less integrated into the global trade in manufactures, and 
have less overall access to the OECD market. (The number of countries from these regions in the sample is small, so the results for these regions must be viewed with caution.)

The results also shed light on the GATT articles, Doha Development Agenda, and on the Singapore issues. Compliance with GATT Article V (freedom of transit) as proxied by the port efficiency indicator, and with Article VIII (fees and formalities connected with importation and exportation), as proxied by the customs environment indicator, would yield a \$107 billion and \$33 billion increase in manufacturing trade, respectively. Compliance with GATT X (publication and administration of trade regulations), as proxied by the regulatory environment indicator would yield an $\$ 83$ billion increase in trade flow. Finally, with respect to services negotiations, improvements in service sector infrastructure could yield $\$ 154$ billion increase in trade. These results should shed light on discussions at the WTO.

Finally, country-specific detail from these simulations, in conjunction with case studies and country-specific knowledge, could help inform and design capacity building to support trade. For example, Lane (2001) suggests that the Latin America region has been lagging behind in terms of customs environment. Our results confirm that LAC could gain from attention to customs. A case study from Peru showed that manual and paperwork-intensive systems resulted in a long clearance time for customs and limited transparency. But Peruvian customs reforms achieved remarkable gains in compliance, cost, and trade facilitation. So case study plus simulation detail, plus country-specific analysis could help other countries follow Peru's lead in reforms. Similarly, the analysis in this paper indicates that South Asia has a large scope for trade promotion from trade facilitation reform. In Bangladesh, a customs modernization program is helping to eradicate the corruption and inefficiency in fee collection. Rapid clearance for exports and their imported inputs, increased automation, efficient risk management systems and staff training are working to achieve this goal (World Bank 1999). Our results point not just to a need to focus on customs, but more broadly to address ports, regulatory environment, and particularly the domestic services infrastructure that support economic activity and trade. Further compilation of case studies in these areas would assist in capacity building efforts.

In conclusion, the results from this paper suggest that the scope and benefit of unilateral trade facilitation reforms are very large and that the gains fall disproportionately on exports. Combining the country detail from these simulations with case study analysis of specific reform efforts and the specifics of a country's trade facilitation challenges can triangulate on a design strategy for capacity building to increase trade and economic well-being. 


\section{Data Appendix}

Data come from the World Economic Forum, Global Competitiveness Report, 2001-02 (GCR), IMD Lausanne, World Competitiveness Yearbook 2002 (WCY), and Kaufmann, Kraay and Zoido-Lobaton (2002) (KKZ). All survey data in GCR comes from the World Economic Forum's Executive Opinion Survey. A total of 4022 firms were surveyed. "In order to provide the basis for a comparative assessment on a global basis, it is essential that we interview a sufficient number of senior business leaders in individual countries and that the sample in each country is not biased in favor of any particular business group. We have taken a number of steps to ensure this. First, we have asked each of our partner institutes, the organizations that administer the surveys in each country, to start with a comprehensive register of firms. From this, they were asked to choose a sample whose distribution across economic sectors was proportional to the distribution of the country's labor force across sectors, excluding agriculture. They were then asked to choose firms randomly within these broad sectors (for example, by choosing firms at regular intervals from an alphabetic list), and to pursue face-to-face interviews, following up for clarifications where necessary. The employment distribution was taken from data in the 1998 Yearbook of Labour Statistics of the International Labour Office. The respondents to the survey are typically a company's CEO or a member of its senior management."

The WCY uses a 115 question survey sent to executives in top and middle management of firms in all 49 countries of the WCY. The sample size of each country is proportional to GDP, and firms "normally have an international dimension." The firms are selected to be a cross section of manufacturing, service, and primary industries. There were 3532 responses to the Survey.

KKZ (2002) updates the data on governance that were developed in Kaufmann, Kraay and Zoido-Lobaton (1999) "Governance Matters." The database contain more than 300 governance indicators for 175 countries compiled from a variety of sources in 2000/2001. Six aggregate indicators are constructed corresponding to six basic governance concepts: Voice and Accountability, Political Stability, Government Effectiveness, Regulatory Quality, Rule of Law and Control of Corruption.

The various raw data series were chosen because of their relevance to the four concepts of trade facilitation.

- Port efficiency for each country $J$ is the average of two indexed inputs (all GCR):

- Port facilities and inland waterways are :(1=underdeveloped, 7=as developed as the world's best, GCR)

- Air transport is :(1=infrequent and inefficient, $7=$ as extensive and efficient as the world's best, GCR)

- Customs environment for each country $J$ is the average of two indexed inputs (all GCR):

Hidden import barriers other than published tariffs and quotas 
- Irregular extra payments or bribes connected with import and export permits

- Regulatory environment for each country $J$ is constructed as the average of four indexed inputs:

○ Transparency of government policy is satisfactory (WCY)

○ Control of Corruption (KKZ)

- Service sector infrastructure for each country $J$ is as the average of three indexed inputs (all GCR):

O Speed and cost of internet access are: $(1=$ slow and expensive, $7=$ fast and cheap)

$\circ$ Internet contribution to reduce inventory costs is: $(1=$ no improvement, $7=$ huge improvement) 


\section{References:}

Anderson, James E. (1979). "A Theoretical Foundation for the Gravity Equation." American Economic Review 69: p.106-116.

Anderson, James E. and Eric van Wincoop (2003). "Gravity with Gravitas: A Solution to the Border Puzzle.” American Economic Review v93, n1: 170-92.

Asia Pacific Economic Co-operation (APEC) (1999). Assessing APEC Trade Liberalization and Facilitation: 1999 Update, Economic Committee, September 1999. APEC: Singapore.

Asia Pacific Foundation of Canada (1999). Survey on Customs, Standards and Business Mobility in the APEC Region. APF Canada: Vancouver.

Balistreri, Edward J. and Russell H. Hillberry (mimeo). "Trade Friction and Welfare in the Gravity Model: How Much of the Iceberg Melts?” U.S. International Trade Commission, Washington, D.C.

Clark, Ximena, David Dollar and Alejandro Micco. (2002). "Maritime Transport Costs and Port Efficiency." World Bank Working Paper Series \# 2781. The World Bank: Washington, D.C.

Dollar, David and Aart Kraay (2001). "Trade, Growth, and Poverty” World Bank Working Paper Series \#2615. The World Bank: Washington D.C.

Fink, Carsten, Aaditya Mattoo and Cristina Ileana Neagu (2002a). "Trade in International Maritime Services: How Much Does Policy Matter?" World Bank Economic Review v16, n1 (2002): 81-108.

Fink, Carsten, Aaditya Mattoo and Cristina Ileana Neagu (2002b). "Assessing the Role of Communication Costs in International Trade." World Bank Working Paper \#2929. The World Bank: Washington, D.C.

Frankel, Jeffrey A and Rose, Andrew K. (2000). "Estimating the Effect of Currency Unions on Trade and Output." National Bureau of Economic Research Working Paper \#7857.

Freund, Caroline and Diana Weinhold (2000). "On the Effect of the Internet on International Trade.” International Finance Discussion Papers \#693, Board of Governors of the Federal Reserve System.

Hertel, Thomas W., Terrie Walmsley; and Ken Itakura (2001). "Dynamic Effect of the "New Age" Free Trade Agreement between Japan and Singapore.” Journal of Economic Integration v16, n4: p. 446-84. 
Hummels, D. (2001). “Time as a Trade Barrier.” Department of Economics, Indiana: Purdue University, Mimeo.

IMD (2000). World Competitiveness Yearbook. IMD: Lausanne.

Kaufmann, Daniel, Aart Kraay, and Pablo Zoido-Lobaton (2002). “Governance Matters II: Updated Indicators for 2000-01” World Bank Working Paper \#2772, The World Bank: Washington, D.C.

Lane, Micahel (2001). International Supply Chain Management and Customs. Peru Case Study, Washington, D.C.: The World Bank.

Mann, Catherine L., Sue E. Eckert, and Sarah Cleeland Knight (2000). Global Electronic Commerce: A Policy Primer. Washington: Institute for International Economics

Mann, Catherine L., Daniel H. Rosen, and APEC (2001, 2002). The New Economy and APEC. Singapore: APEC Secretariat; reprinted (2002) Washington: Institute for International Economics.

Maskus, Keith E., John S. Wilson and Tsunehiro Otsuki (2001). “An Empirical Framework for Analyzing Technical Regulations and Trade" in Quantifying the impact of technical barriers to trade: Can it be done? Keith Maskus and John S. Wilson eds.

Messerlin, Patrick A and J. Zarrouk (1999). "Trade Facilitation: Technical Regulation and Customs Procedures." September 1999 for the WTO/World Bank Conference on Developing Countries in a Millennium Round.

Moenius, Johannes (2000). Three Essays on Trade Barriers and Trade Volumes. Ph.D. dissertation, University of California, San Diego.

Otsuki, Tsunehiro, John S. Wilson, and Mirvat Sewadeh (2001a) "What Price Precaution? European Harmonisation of Aflatoxin regulations and African groundnut exports."

European Review of Agricultural Economics vol. 28, no. 3: 263-284.

Otsuki, Tsunehiro, John S. Wilson, and Mirvat Sewadeh (2001b). "Saving Two in a Billion: Quantifying the Trade Effect of European Food Safety Standards on African Exports." Food Policy 26.

United Nations Conference on Trade and Development (2001). E-Commerce and Development Report. UNCTAD: Geneva.

White, H. (1980). “A Heterosckedasticity-consistent Covariance Matrix Estimator and a Direct Test for Heteroscedasticity." Econometrica 48: 817-838. 
Wilson, John S., Catherine L. Mann, and Tsunehiro Otsuki (2003). "Trade Facilitation and Economic Development: Measuring the Impact.” World Bank Working Paper \#2988. World Bank: Washington D.C.

Winters, L. Alan (2004) “Globalization and Small Countries", presented at ASSA meetings, San Diego (January).

World Bank (1999). Project Appraisal Document on a Proposed Credit in the Amount of US\$32 Million Equivalent to Bangladesh for an Export Diversification Project. The World Bank: Washington DC.

World Economic Forum (2001). Global Competitiveness Report. World Economic Forum: Geneva. 
Table 1: Summary Statistics for Values of Trade Facilitation Indicators

\begin{tabular}{|c|c|c|c|c|c|c|c|c|}
\hline Category & Indexed inputs & Source & Mean & $\begin{array}{l}\text { Std. } \\
\text { Dev. }\end{array}$ & Min & $\begin{array}{c}\text { Min. } \\
\text { Importer }\end{array}$ & Max & $\begin{array}{c}\text { Max. } \\
\text { Importer } \\
\end{array}$ \\
\hline Port Efficiency & Ports Facilities & GCR & .636 & .189 & .261 & Bolivia & 1.000 & Singapore \\
\hline & Air Transport & GCR & .710 & .166 & .229 & $\begin{array}{c}\text { Slovak } \\
\text { Republic } \\
\end{array}$ & 1.000 & Singapore \\
\hline Aggregate Index & & & .673 & .169 & .345 & Bolivia & 1.000 & Singapore \\
\hline Customs Environment $I$ & Hidden Import Barriers & GCR & .702 & .167 & .368 & Paraguay & 1.000 & Finland \\
\hline & Bribery & GCR & .689 & .175 & .343 & Bangladesh & 1.000 & Iceland \\
\hline Aggregate Index & & & .695 & .163 & .384 & Paraguay & 0.979 & Finland \\
\hline \begin{tabular}{|l} 
Regulatory \\
Environment
\end{tabular} & $\begin{array}{l}\text { Transparency of Government } \\
\text { Policies }\end{array}$ & WCY & .619 & .205 & .089 & Argentina & 1.000 & Finland \\
\hline & Control of Corruption & $\mathrm{KKZ}$ & .746 & .140 & .530 & South Africa & 1.000 & Finland \\
\hline Aggregate Index & & & .689 & .139 & .353 & Venezuela & 1.000 & Finland \\
\hline $\begin{array}{l}\text { Service sector } \\
\text { infrastructure }\end{array}$ & Speed and Costs of Internet Access & GCR & .629 & .162 & .348 & Vietnam & 1.000 & Finland \\
\hline & Effect on Internet on Business & GCR & .719 & .102 & .481 & Greece & 1.000 & Finland \\
\hline Aggregate Index & & & 674 & .121 & .482 & Mauritius & 1.000 & Finland \\
\hline
\end{tabular}

Source: Authors' calculation based on Global Competitiveness Report 2001-2002, Kaufmann, Kraay and Zoido-Lobaton (2002) and World Competitiveness Yearbook 2002. 
Figure 1: Two Indexed inputs to Port Efficiency

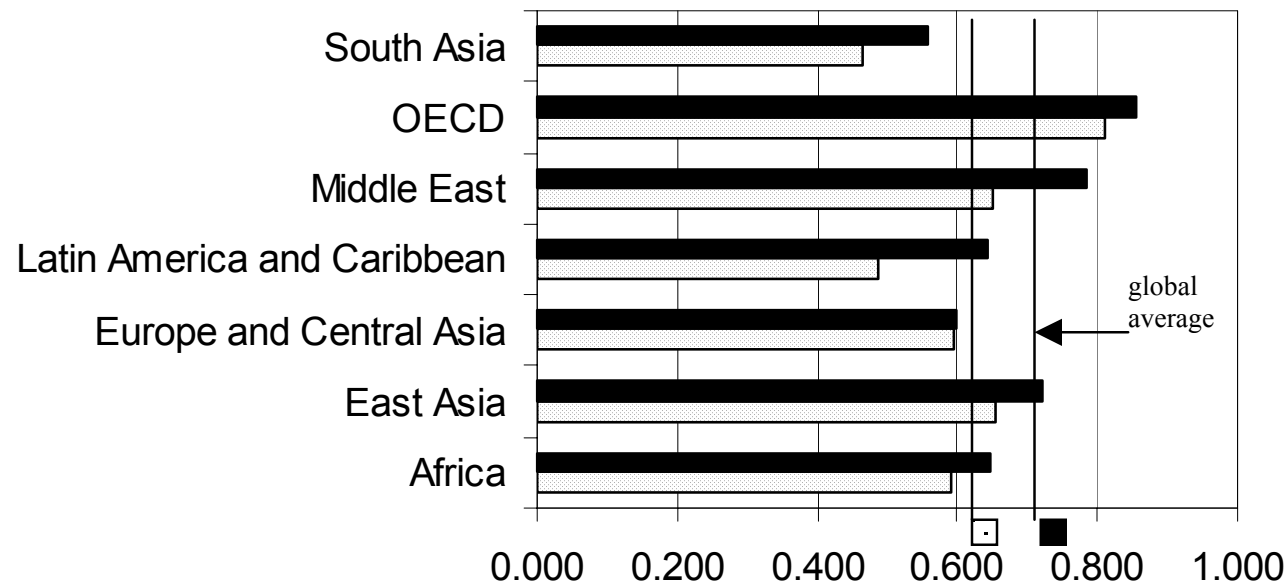

Air transport (higher is better)

$\square$ Inland w aterw ays (higher is better)

Source: Authors' calculation based on Global Competitiveness Report 2001-2002.

Figure 2: Two Indexed inputs to customs environment

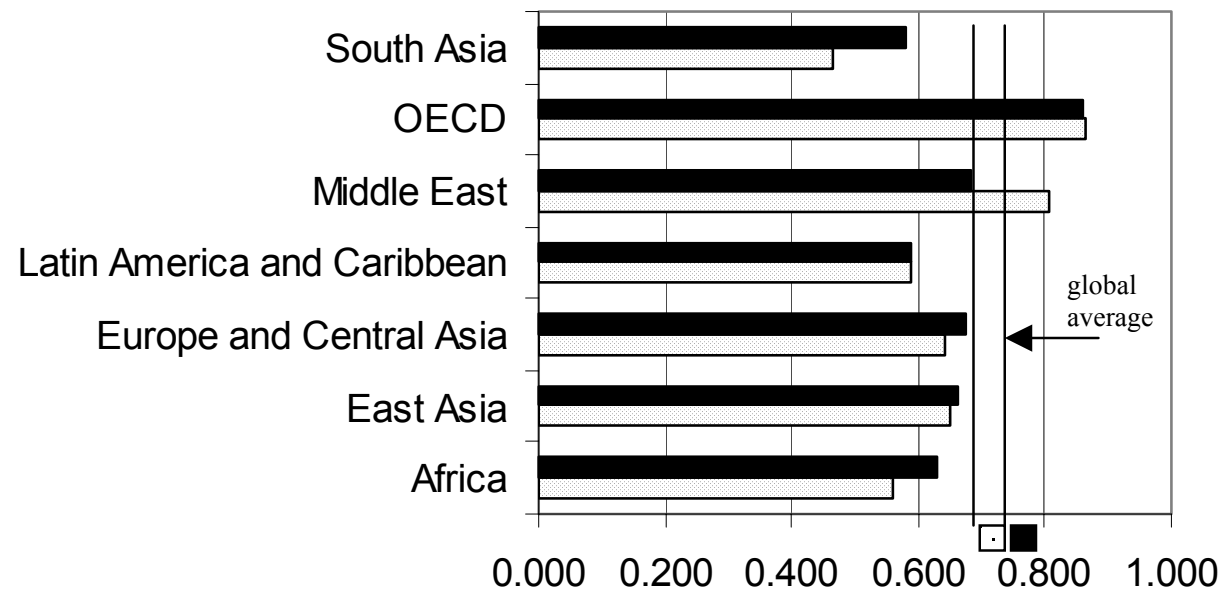

Source: Authors' calculation based on Global Competitiveness Report 2001-2002. 
Figure 3: Two Indexed Inputs to Regulatory Environment

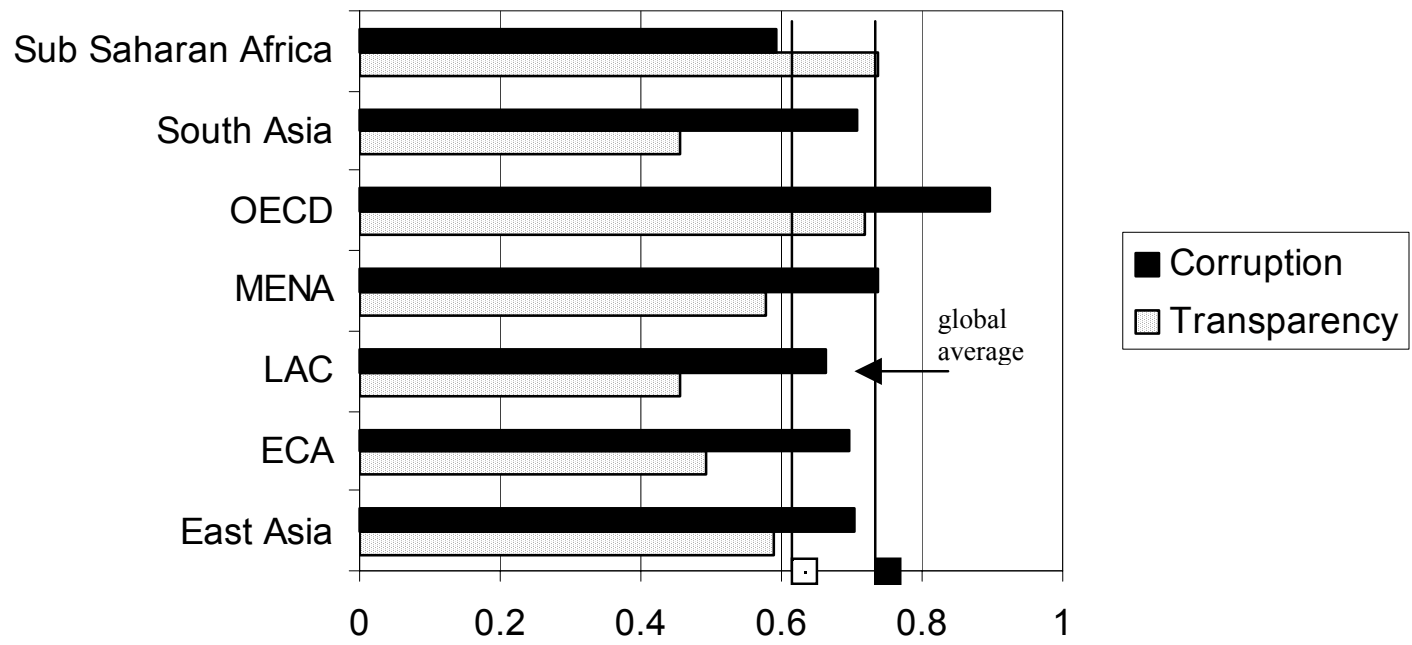

Source: Authors' calculation based on Kaufmann, Kraay and Zoido-Lobaton (2002) and World Competitiveness Yearbook 2002.

Figure 4: Two Indexed inputs to Service-Sector Infrastructure

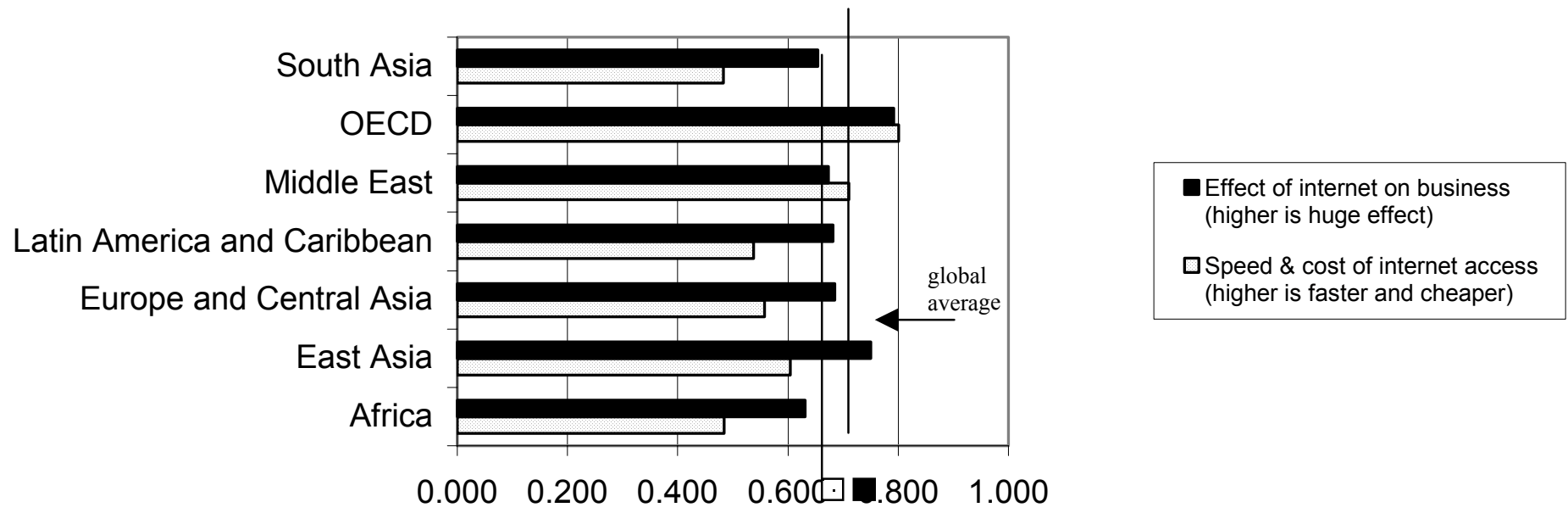

Source: Authors' calculation based on Global Competitiveness Report 2001-2002. 
Table 2: Correlation Matrix of Key Variables for Gravity Model

\begin{tabular}{|c|c|c|c|c|c|c|c|c|c|c|c|}
\hline & Trade & Tariff & $\begin{array}{l}\text { Port } \\
\text { Efficiency }\end{array}$ & $\begin{array}{l}\text { Customs } \\
\text { Environm } \\
\text { ent }\end{array}$ & $\begin{array}{l}\text { Regulator } \\
\text { y } \\
\text { Environm } \\
\text { ent }\end{array}$ & $\begin{array}{l}\text { Service } \\
\text { sector } \\
\text { infrastruct } \\
\text { ure } \\
\end{array}$ & $\begin{array}{l}\text { GNP of } \\
\text { Importer }\end{array}$ & $\begin{array}{l}\text { GNP of } \\
\text { Exporter }\end{array}$ & $\begin{array}{l}\text { Per capita } \\
\text { GNP of } \\
\text { Importer }\end{array}$ & $\begin{array}{l}\text { Per capita } \\
\text { GNP of } \\
\text { Exporter }\end{array}$ & Distance \\
\hline Trade & 1 & & & & & & & & & & \\
\hline Tariff & -0.154 & 1 & & & & & & & & & \\
\hline Port Efficiency & 0.239 & -0.311 & 1 & & & & & & & & \\
\hline Customs Environment & 0.221 & -0.335 & 0.767 & 1 & & & & & & & \\
\hline $\begin{array}{l}\text { Regulatory } \\
\text { Environment }\end{array}$ & 0.078 & -0.295 & 0.600 & 0.709 & 1 & & & & & & \\
\hline $\begin{array}{l}\text { Service sector } \\
\text { infrastructure }\end{array}$ & 0.255 & -0.362 & 0.784 & 0.762 & 0.608 & 1 & & & & & \\
\hline GNP of Importer & 0.444 & -0.171 & 0.444 & 0.398 & 0.064 & 0.490 & 1 & & & & \\
\hline GNP of Exporter & 0.614 & -0.024 & -0.040 & -0.051 & -0.015 & -0.051 & -0.064 & 1 & & & \\
\hline $\begin{array}{l}\text { Per capita GNP of } \\
\text { Importer }\end{array}$ & 0.255 & -0.399 & 0.795 & 0.858 & 0.570 & 0.787 & 0.491 & -0.055 & 1 & & \\
\hline $\begin{array}{l}\text { Per capita GNP of } \\
\text { Exporter }\end{array}$ & 0.399 & -0.099 & -0.026 & -0.031 & -0.009 & -0.032 & -0.036 & 0.504 & -0.035 & 1 & \\
\hline Distance & -0.364 & 0.063 & -0.091 & -0.128 & -0.081 & -0.074 & -0.019 & 0.013 & -0.129 & -0.115 & 1 \\
\hline
\end{tabular}

Source: Authors' calculation. 
Table 3: Regression Results

\begin{tabular}{|c|c|c|c|c|}
\hline & \multicolumn{2}{|c|}{ Model 1} & \multicolumn{2}{|c|}{ Model 2} \\
\hline & Coef. & Std. Err. & Coef. & Std. Err. \\
\hline Constant & $-10.641^{* * *}$ & 1.558 & $-10.771 * * *$ & 1.549 \\
\hline Tariff Rates & $-1.155^{* * *}$ & 0.318 & $-1.163^{* * *}$ & 0.318 \\
\hline Port Efficiency of Importer & $0.307 *$ & 0.163 & $0.338 *$ & 0.160 \\
\hline Port Efficiency of Exporter & $0.924 * * *$ & 0.148 & $0.938 * * *$ & 0.146 \\
\hline Customs Environment of Importer & $0.472 * *$ & 0.199 & $0.486^{*}$ & 0.199 \\
\hline Regulatory Envornment of Importer & $0.281 *$ & 0.144 & 0.264 & 0.144 \\
\hline Regulatory Envornment of Exporter & $0.620 * * *$ & 0.132 & $0.580 * * *$ & 0.131 \\
\hline Service sector infrastructure of Importer & $0.729 * * *$ & 0.224 & $0.657 * *$ & 0.224 \\
\hline Service sector infrastructure of Exporter & $1.943 * * *$ & 0.216 & $1.943 * * *$ & 0.217 \\
\hline GNP of Importer & $0.915 * * *$ & 0.014 & $0.915 * * *$ & 0.014 \\
\hline Per capita GNP of Importer & $-0.182 * * *$ & 0.037 & $-0.210 * * *$ & 0.037 \\
\hline GNP of Exporter & $1.246^{* * *}$ & 0.014 & $1.241 * * *$ & 0.014 \\
\hline Per capita GNP of Exporter & $-0.226^{* * *}$ & 0.029 & $-0.251 * * *$ & 0.029 \\
\hline Geographical Distance & $-1.258 * * *$ & 0.025 & $-1.225 * * *$ & 0.025 \\
\hline Adjacency dummy & $0.336^{* * *}$ & 0.114 & $0.426 * * *$ & 0.108 \\
\hline Membership Dummy for any FTA & & & -0.021 & 0.078 \\
\hline ASEAN Membership Dummy & $0.509 * * *$ & 0.190 & & \\
\hline NAFTA Membership Dummy & -0.645 & 0.501 & & \\
\hline LAIA Membership Dummy & $0.593 * * *$ & 0.154 & & \\
\hline AUNZ Membership Dummy & 1.118 & 0.858 & & \\
\hline MERCOSUR Membership Dummy & 0.229 & 0.302 & & \\
\hline EU Membership Dummy & $-0.515^{* * *}$ & 0.106 & & \\
\hline Dummy for any Common Language & & & $0.823 * * *$ & 0.061 \\
\hline English Language Dummy & $0.808^{* * *}$ & 0.089 & & \\
\hline French Language Dummy & $-1.413 * * *$ & 0.500 & & \\
\hline Spanish Language Dummy & $0.598^{* * *}$ & 0.098 & & \\
\hline Arabic Language Dummy & -1.223 & 0.992 & & \\
\hline Chinese Language Dummy & $1.747 * * *$ & 0.406 & & \\
\hline German Language Dummy & -0.826 & 0.505 & & \\
\hline Portuguese Language Dummy & 0.569 & 0.986 & & \\
\hline Russian Language Dummy & $2.026^{* * *}$ & 0.362 & & \\
\hline Year 2000 dummy & -0.031 & 0.039 & -0.038 & 0.039 \\
\hline Adjusted R-squared & 0.758 & & 0.755 & \\
\hline Number of the observations & 7,904 & & 7,904 & \\
\hline
\end{tabular}

Note: The significance levels at $10 \%, 5 \%$ and $1 \%$ are denoted by “*”, “**”, and “***”, recpectively.

Source: Authors' calculation. 
Table 4: Regression Results (South to South and South to North Trade)

\begin{tabular}{|c|c|c|c|}
\hline & Full sample & $\begin{array}{l}\text { South to north } \\
\text { trade }\end{array}$ & $\begin{array}{l}\text { South to south } \\
\text { trade }\end{array}$ \\
\hline Tariff rates & $-1.555 * * *$ & -1.512 & $-1.5^{* * * *}$ \\
\hline Port Efficiency of Importing Country & $0.307^{*}$ & 0.344 & -0.283 \\
\hline Port Efficiency of Exporting Country & $0.924 * * *$ & $0.845 * * *$ & $0.949 * * *$ \\
\hline Customs Environment of Importing Country & $0.472 * *$ & 1.041 & 0.202 \\
\hline Regulatory Environment of Importing Country & $0.281 *$ & $-1.120 *$ & $0.816^{* * *}$ \\
\hline Regulatory Environment of Exporting Country & $0.620 * * *$ & $2.437 * * *$ & $0.827 * * *$ \\
\hline Service sector infrastructure of Importing Country & $0.729 * * *$ & $2.134 * * *$ & 0.866 \\
\hline Service sector infrastructure of Exporting Country & $1.943 * * *$ & $2.124 * * *$ & $3.133 * * *$ \\
\hline Adjusted R-squared & 0.758 & 0.702 & 0.649 \\
\hline Number of the observations & 7,904 & 2,188 & 3,094 \\
\hline
\end{tabular}


Table 5. The Effect of Port Efficiency by Geographical Characteristics

\begin{tabular}{|c|c|c|c|c|c|}
\hline Port Efficiency of Importer & $0.333 * *$ & $0.311 *$ & $0.368 * *$ & $0.303 *$ & $0.357 * *$ \\
\hline & $(0.165)$ & $(0.163)$ & $(0.164)$ & $(0.165)$ & $(0.166)$ \\
\hline \multirow[t]{2}{*}{ Landlockedness* Port Efficiency of Importer } & -0.157 & & & -0.128 & -0.126 \\
\hline & $(0.783)$ & & & $(0.783)$ & $(0.781)$ \\
\hline \multirow[t]{2}{*}{ Island* Port Efficiency of Importer } & & $1.198 * *$ & & $1.223 * *$ & $1.307^{* *}$ \\
\hline & & $(0.604)$ & & $(0.606)$ & $(0.605)$ \\
\hline \multirow[t]{2}{*}{ Adjacency* Port Efficiency of Importer } & & & $-1.360 * * *$ & & $-1.333 * * *$ \\
\hline & & & $(0.409)$ & & $(0.410)$ \\
\hline \multirow[t]{2}{*}{ Port Efficiency of Exporter } & $0.940 * * *$ & $0.866^{* * *}$ & $1.007 * * *$ & $0.982 * * *$ & $1.057 * * *$ \\
\hline & $(0.149)$ & $(0.149)$ & $(0.149)$ & $(0.150)$ & $(0.150)$ \\
\hline \multirow[t]{2}{*}{ Landlockedness* Port Efficiency of Exporter } & 0.268 & & & 0.229 & 0.424 \\
\hline & $(0.836)$ & & & $(0.835)$ & $(0.835)$ \\
\hline \multirow[t]{2}{*}{ Island* Port Efficiency of Exporter } & & $-2.000 * * *$ & & $-2.107 * * *$ & $-2.038 * * *$ \\
\hline & & $(0.612)$ & & $(0.614)$ & $(0.612)$ \\
\hline \multirow[t]{2}{*}{ Adjacency* Port Efficiency of Exporter } & & & $-1.582 * * *$ & & $-1.592 * * *$ \\
\hline & & & $(0.388)$ & & $(0.389)$ \\
\hline \multirow[t]{2}{*}{ Customs Environment of Importer } & $0.461^{* *}$ & $0.461 * *$ & $0.431^{* *}$ & $0.444 * *$ & $0.402 * *$ \\
\hline & $(0.200)$ & $(0.199)$ & $(0.199)$ & $(0.200)$ & $(0.199)$ \\
\hline \multirow[t]{2}{*}{ Regulatory Envornment of Importer } & $0.283^{* *}$ & $0.294 * *$ & $0.279 *$ & $0.288 * *$ & $0.287 * *$ \\
\hline & $(0.144)$ & $(0.143)$ & $(0.143)$ & $(0.144)$ & $(0.143)$ \\
\hline \multirow[t]{2}{*}{ Regulatory Envornment of Exporter } & $0.619 * * *$ & $0.608 * * *$ & $0.607 * * *$ & $0.624 * * *$ & $0.610 * * *$ \\
\hline & $(0.132)$ & $(0.132)$ & $(0.132)$ & $(0.132)$ & $(0.132)$ \\
\hline \multirow[t]{2}{*}{ Service sector infrastructure of Importer } & $0.713 * * *$ & $0.745 * * *$ & $0.753 * * *$ & $0.764 * * *$ & $0.791 * * *$ \\
\hline & $(0.225)$ & $(0.224)$ & $(0.224)$ & $(0.225)$ & $(0.225)$ \\
\hline \multirow[t]{2}{*}{ Service sector infrastructure of Exporter } & $1.936^{* * *}$ & $2.002 * * *$ & $1.944 * * *$ & $1.867 * * *$ & $1.874 * * *$ \\
\hline & $(0.217)$ & $(0.218)$ & $(0.216)$ & $(0.218)$ & $(0.217)$ \\
\hline \multirow[t]{2}{*}{ Tariff Rates } & $-1.161 * * *$ & $-1.239 * * *$ & $-1.127 * * *$ & $-1.205^{* * *}$ & $-1.177 * * *$ \\
\hline & $(0.319)$ & $(0.318)$ & $(0.318)$ & $(0.318)$ & $(0.318)$ \\
\hline \multirow[t]{2}{*}{ Landlockedness Dummy } & 0.328 & & & 0.324 & 0.386 \\
\hline & $(0.794)$ & & & $(0.793$ & $(0.791)$ \\
\hline \multirow[t]{2}{*}{ Island Dummy } & & -0.260 & & -0.263 & -0.222 \\
\hline & & $(0.483)$ & & $(0.370)$ & $(0.370)$ \\
\hline \multirow[t]{2}{*}{ Adjacency Dummy } & $0.329 * * *$ & $0.331 * * *$ & $-0.955 * * *$ & $0.329 * * *$ & $-0.953 * * *$ \\
\hline & $(0.114)$ & $(0.113)$ & $(0.235)$ & $(0.114)$ & $(0.235)$ \\
\hline Adjusted R-squared & 0.759 & 0.761 & 0.760 & 0.760 & 0.761 \\
\hline
\end{tabular}

Note: The significance levels at $10 \%, 5 \%$ and $1 \%$ are denoted by “*”, “**”, and “***”, recpectively.

Source: Authors' calculation. 
Table 6. Robustness Check for the OLS Estimator

\begin{tabular}{|c|c|c|c|c|c|c|}
\hline Variable & OLS & Huber/White & Huber/White & Huber/White & WLS & WLS \\
\hline \multirow[t]{2}{*}{ Tariff Rates } & $-1.155^{* * *}$ & $-1.155^{* * *}$ & -1.155 & $-1.155^{* *}$ & $-1.467 * * *$ & $-0.483^{* *}$ \\
\hline & $(0.318)$ & $(0.399)$ & $(0.868)$ & $(0.561)$ & $(0.343)$ & $(0.246)$ \\
\hline \multirow[t]{2}{*}{ Port Efficiency of Importer } & $0.307^{*}$ & $0.307^{*}$ & 0.307 & 0.307 & 0.246 & $0.473 * * *$ \\
\hline & $(0.163)$ & $(0.161)$ & $(0.414)$ & $(0.204)$ & $(0.157)$ & $(0.119)$ \\
\hline \multirow[t]{2}{*}{ Port Efficiency of Exporter } & $0.924 * * *$ & $0.924 * * *$ & $0.924 * * *$ & 0.924 & $0.913 * * *$ & $0.537 * * *$ \\
\hline & $(0.148)$ & $(0.166)$ & $(0.179)$ & $(0.978)$ & $(0.142)$ & $(0.137)$ \\
\hline \multirow[t]{2}{*}{ Customs Environment of Importer } & $0.472 * *$ & $0.472 * *$ & 0.472 & $0.472 *$ & $0.472 * *$ & $1.112 * * *$ \\
\hline & $(0.199)$ & $(0.198)$ & $(0.480)$ & $(0.259)$ & $(0.193)$ & $(0.147)$ \\
\hline \multirow[t]{2}{*}{ Regulatory Envornment of Importer } & $0.281^{*}$ & $0.281 * *$ & 0.281 & $0.281^{*}$ & $0.288 * *$ & -0.069 \\
\hline & $(0.144)$ & $(0.141)$ & $(0.304)$ & $(0.145)$ & $(0.138)$ & $(0.107)$ \\
\hline \multirow[t]{2}{*}{ Regulatory Envornment of Exporter } & $0.620 * * *$ & $0.620 * * *$ & $0.620 * * *$ & 0.620 & $0.594 * * *$ & 0.180 \\
\hline & $(0.132)$ & $(0.144)$ & $(0.163)$ & $(0.867)$ & $(0.127)$ & $(0.118)$ \\
\hline \multirow[t]{2}{*}{ Service sector infrastructure of Importer } & $0.729 * * *$ & $0.729 * * *$ & 0.729 & $0.729 * * *$ & $0.647 * * *$ & $0.494 * * *$ \\
\hline & $(0.224)$ & $(0.241)$ & $(0.771)$ & $(0.262)$ & $(0.227)$ & $(0.166)$ \\
\hline \multirow[t]{2}{*}{ Service sector infrastructure of Exporter } & $1.943 * * *$ & $1.943 * * *$ & $1.943 * * *$ & 1.943 & $1.831 * * *$ & $2.336^{* * *}$ \\
\hline & $(0.216)$ & $(0.234)$ & $(0.242)$ & $(1.270)$ & $(0.208)$ & $(0.189)$ \\
\hline \multirow[t]{2}{*}{ GNP of Importer } & $0.915 * * *$ & $0.915 * * *$ & $0.915 * * *$ & $0.915 * * *$ & $0.931 * * *$ & $0.892 * * *$ \\
\hline & $(0.014)$ & $(0.015)$ & $(0.044)$ & $(0.018)$ & $(0.014)$ & $(0.010)$ \\
\hline \multirow[t]{2}{*}{ Per capita GNP of Importer } & $-0.182 * * *$ & $-0.182 * * *$ & $-0.182 *$ & $-0.182 * * *$ & $-0.183 * * *$ & $-0.227 * * *$ \\
\hline & $(0.037)$ & $(0.038)$ & $(0.099)$ & $(0.056)$ & $(0.037)$ & $(0.028)$ \\
\hline \multirow[t]{2}{*}{ GNP of Exporter } & $1.246^{* * *}$ & $1.246^{* * *}$ & $1.246 * * *$ & $1.246^{* * *}$ & $1.239 * * *$ & $1.169^{* * *}$ \\
\hline & $(0.014)$ & $(0.015)$ & $(0.020)$ & $(0.082)$ & $(0.014)$ & $(0.012)$ \\
\hline \multirow[t]{2}{*}{ Per capita GNP of Exporter } & $-0.226 * * *$ & $-0.226^{* * *}$ & $-0.226 * * *$ & -0.226 & $-0.231 * * *$ & $-0.153 * * *$ \\
\hline & $(0.029)$ & $(0.030)$ & $(0.032)$ & $(0.197)$ & $(0.028)$ & $(0.022)$ \\
\hline \multirow[t]{2}{*}{ Geographical Distance } & $-1.258 * * *$ & $-1.258 * * *$ & $-1.258 * * *$ & $-1.258 * * *$ & $-1.238 * * *$ & $-1.143 * * *$ \\
\hline & $(0.025)$ & $(0.022)$ & $(0.048)$ & $(0.092)$ & $(0.025)$ & $(0.018)$ \\
\hline Robust Standard Error & No & Yes & Yes & Yes & & \\
\hline Cluster & & No & Importer & Exporter & & \\
\hline Weighted Least Square & & & & & Yes & Yes \\
\hline Cluster & & & & & Importer & Exporter \\
\hline Adjusted R-squared & 0.759 & 0.759 & 0.759 & 0.759 & & \\
\hline Chi-squared against all b being zero & & & & & 26,755 & 38,700 \\
\hline
\end{tabular}

Note: The significance levels at $10 \%, 5 \%$ and $1 \%$ are denoted by “*”, “**”, and “***”, recpectively. Source: Authors' calculation. 
Figure 5: Changes in Trade Facilitation Measures to Have an Equivalent Increase in Trade Flow to a Total Elimination of Tariffs in Manufacture

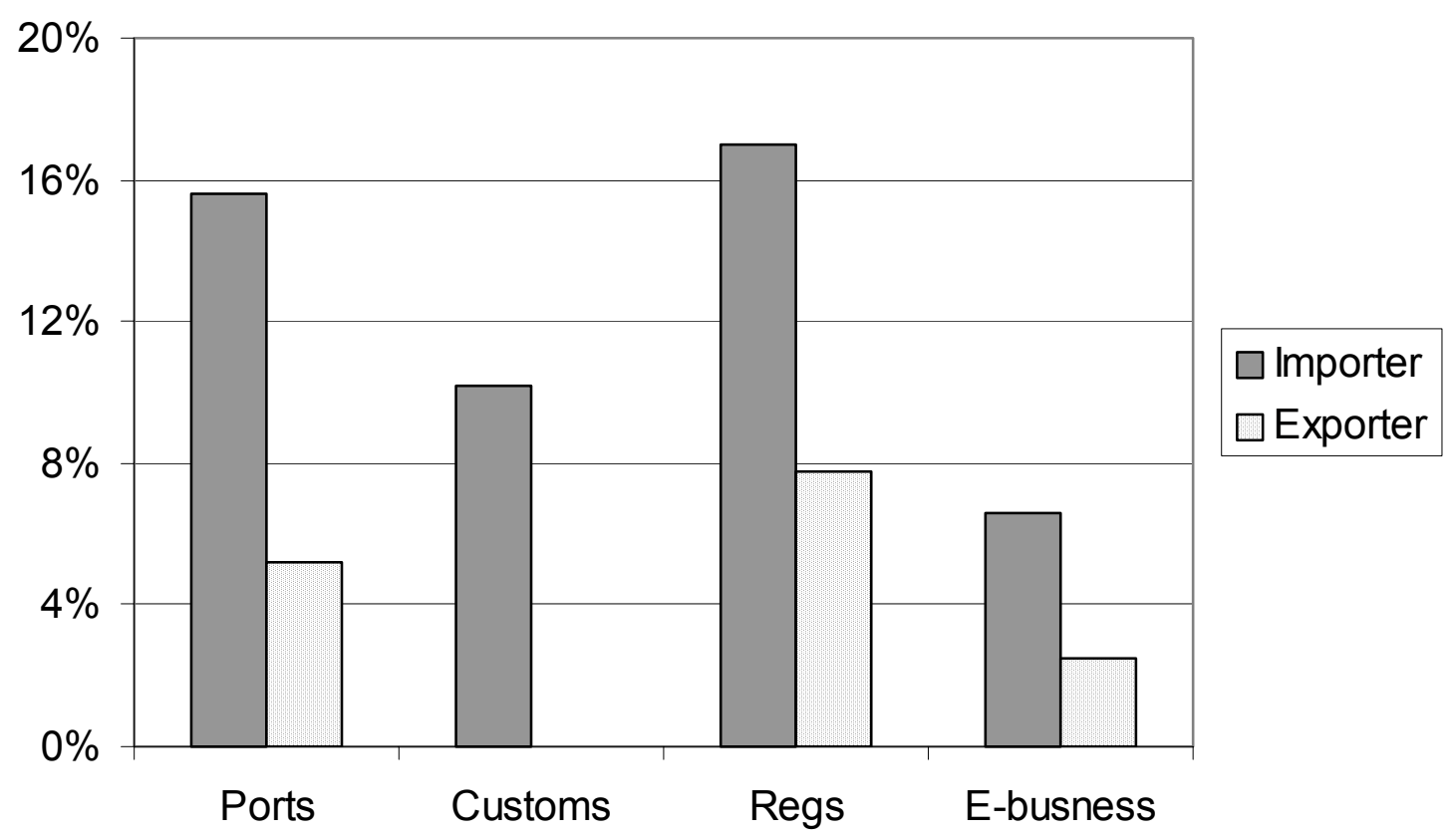

Source: Authors' calculation. 
Figure 6: Simulation Analysis: Improvements in Trade Facilitation and Change in Trade Flows

\section{Experience of Exporters}

\begin{tabular}{l|l|l|}
\begin{tabular}{l|l} 
Total \$ Change in \\
Exports from Country $\mathrm{X}$
\end{tabular}$=$ & $\begin{array}{l}\text { \$Change in Country } \\
\text { X's Exports from } \\
\text { Country X's Own } \\
\text { Improvements }\end{array}$
\end{tabular}

Experience of Importers

\begin{tabular}{|l|l|l|}
$\begin{array}{l}\text { Total \$ Change in } \\
\text { Imports from Country X }\end{array}=$ & $\begin{array}{l}\text { \$ Change in Country } \\
\text { X's Imports from } \\
\text { Country X's Own } \\
\text { Improvements }\end{array}$
\end{tabular}

Table 7: Overview of Simulation: Bring Below-Average Members Half-way up to the Global Average (Change in Trade Flow in \$ billion)

\begin{tabular}{|l|l|l|l|}
\hline & $\begin{array}{l}\text { Importer's } \\
\text { change in trade } \\
\text { facilitation }\end{array}$ & $\begin{array}{l}\text { Exporter's } \\
\text { change in trade } \\
\text { facilitation }\end{array}$ & Total \\
\hline 'Border' Measures & & & \\
\hline Port Efficiency & $23.40(0.6 \%)$ & $84.53(2.2 \%)$ & $106.93(2.8 \%)$ \\
\hline Customs Environment & $32.87(0.8 \%)$ & & $32.87(0.8 \%)$ \\
\hline $\begin{array}{l}\text { 'Inside-the Border' } \\
\text { Measures }\end{array}$ & & & \\
\hline $\begin{array}{l}\text { Service sector } \\
\text { infrastructure }\end{array}$ & $36.64(0.9 \%)$ & $117.38(3.0 \%)$ & $154.02(4.0 \%)$ \\
\hline $\begin{array}{l}\text { Regulatory } \\
\text { Environment }\end{array}$ & $24.39(0.6 \%)$ & $58.86(1.5 \%)$ & $83.25(2.1 \%)$ \\
\hline & & & \\
\hline \multicolumn{1}{|c|}{ Grand Total } & $117.30(3.0 \%)$ & $259.77(6.7 \%)$ & $377.06(9.7 \%)$ \\
\hline
\end{tabular}

Source: Authors' calculation. 
Table 8: Detail of Simulation Results

\begin{tabular}{|c|c|c|c|c|c|c|c|c|c|c|c|c|}
\hline \multirow[b]{2}{*}{ Region } & \multirow[b]{2}{*}{$\begin{array}{l}\text { Initial } \\
\text { Trade }\end{array}$} & \multicolumn{3}{|c|}{ Port efficiency } & \multirow{2}{*}{\begin{tabular}{|l|}
$\begin{array}{l}\text { Customs } \\
\text { environment }\end{array}$ \\
Total \\
Change, \\
percent
\end{tabular}} & \multicolumn{3}{|c|}{ Regulatory environment } & \multicolumn{3}{|c|}{ Service sector infrastructure } & \multirow{2}{*}{\begin{tabular}{|l} 
Combined \\
Effect
\end{tabular}} \\
\hline & & $\begin{array}{l}\text { Importer } \\
\text { Change, } \\
\text { percent }\end{array}$ & \begin{tabular}{|l|} 
Exporter \\
Change, \\
percent
\end{tabular} & \begin{tabular}{|l|} 
Total \\
Change, \\
percent
\end{tabular} & & $\begin{array}{l}\text { Importer } \\
\text { Change, } \\
\text { percent }\end{array}$ & $\begin{array}{l}\text { Exporter } \\
\text { Change, } \\
\text { percent }\end{array}$ & \begin{tabular}{|l} 
Total \\
Change, \\
percent
\end{tabular} & $\begin{array}{l}\text { Importer } \\
\text { Change, } \\
\text { percent }\end{array}$ & $\begin{array}{l}\text { Exporter } \\
\text { Change, } \\
\text { percent }\end{array}$ & \begin{tabular}{|l|} 
Total \\
Change, \\
percent
\end{tabular} & \\
\hline East Asia & 753 & 0.5 & 7.0 & 7.6 & 0.8 & 0.6 & 3.3 & 3.9 & 0.9 & 10.8 & 11.7 & 24.0 \\
\hline East Europe and Central Asia & 139 & 0.8 & 8.7 & 9.5 & 0.9 & 0.7 & 5.5 & 6.1 & 1.4 & 12.1 & 13.5 & 30.0 \\
\hline Latin America and Caribbean & 179 & 0.6 & 7.3 & 7.9 & 0.9 & 0.8 & 3.6 & 4.4 & 0.8 & 6.0 & 6.8 & 20.0 \\
\hline Middle East and North Africa & 26 & 0.4 & 0.2 & 0.6 & 0.7 & 0.5 & 0.1 & 0.6 & 0.7 & 0.7 & 1.4 & 3.3 \\
\hline OECD & 2735 & 0.6 & 0.0 & 0.7 & 0.8 & 0.6 & 0.6 & 1.3 & 1.0 & 0.0 & 1.0 & 3.8 \\
\hline South Asia & 36 & 0.4 & 11.7 & 12.1 & 0.8 & 0.5 & 6.9 & 7.4 & 0.7 & 19.2 & 20.0 & 40.3 \\
\hline Sub-Saharan Africa & 12 & 0.4 & 1.1 & 1.4 & 0.6 & 0.5 & 2.8 & 3.3 & 0.8 & 4.8 & 5.6 & 10.9 \\
\hline Total & 3879 & 0.6 & 2.2 & 2.8 & 0.8 & 0.6 & 1.5 & 2.1 & 0.9 & 3.0 & 4.0 & 9.7 \\
\hline
\end{tabular}

\section{Source: Authors' calculation.}

--Experience of Importers

\begin{tabular}{|c|c|c|c|c|c|c|c|c|c|c|c|c|}
\hline \multirow[b]{2}{*}{ Region } & \multirow[b]{2}{*}{$\begin{array}{l}\text { Initial } \\
\text { Trade }\end{array}$} & \multicolumn{3}{|c|}{ Port efficiency } & \multirow{2}{*}{\begin{tabular}{|l|} 
Customs \\
environment
\end{tabular}} & \multicolumn{3}{|c|}{ Regulatory environment } & \multicolumn{3}{|c|}{ Service sector infrastructure } & \multirow{2}{*}{ 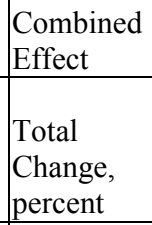 } \\
\hline & & $\begin{array}{l}\text { Importer } \\
\text { Change, } \\
\text { percent }\end{array}$ & $\begin{array}{l}\text { Exporter } \\
\text { Change, } \\
\text { percent }\end{array}$ & \begin{tabular}{|l|} 
Total \\
Change, \\
percent \\
\end{tabular} & & $\begin{array}{l}\text { Importer } \\
\text { Change, } \\
\text { percent }\end{array}$ & \begin{tabular}{|l|} 
Exporter \\
Change, \\
percent
\end{tabular} & $\begin{array}{l}\text { Total } \\
\text { Change, } \\
\text { percent }\end{array}$ & $\begin{array}{l}\text { Importer } \\
\text { Change, } \\
\text { percent }\end{array}$ & $\begin{array}{l}\text { Exporter } \\
\text { Change, } \\
\text { percent }\end{array}$ & $\begin{array}{l}\text { Total } \\
\text { Change, } \\
\text { percent }\end{array}$ & \\
\hline East Asia & 620 & 1.5 & 2.7 & 4.2 & 2.2 & 1.1 & 2.1 & 3.3 & 2.7 & 4.4 & 7.0 & 16.7 \\
\hline East Europe and Central Asia & 165 & 3.1 & 1.8 & 4.9 & 3.2 & 2.7 & 1.3 & 4 & 5.3 & 2.4 & 7.7 & 19.8 \\
\hline Latin America and Caribbean & 260 & 2.9 & 1.3 & 4.2 & 3.4 & 2.4 & 1.4 & 3.8 & 2.9 & 1.8 & 4.7 & 16.1 \\
\hline Middle East and North Africa & 32 & 0.2 & 1.0 & 1.3 & 1.3 & 0.1 & 1.1 & 1.2 & 0.7 & 2.1 & 2.8 & 6.6 \\
\hline OECD & 2761 & 0.0 & 2.2 & 2.2 & 0.1 & 0.2 & 1.4 & 1.6 & 0.1 & 2.9 & 3.0 & 6.9 \\
\hline South Asia & 21 & 3.1 & 1.4 & 4.5 & 5.8 & 3.3 & 1.5 & 4.8 & 6.8 & 2.5 & 9.3 & 24.4 \\
\hline Sub-saharan Africa & 20 & 1.5 & 1.5 & 3.0 & 3.0 & 1.8 & 1.3 & 3.1 & 3.5 & 2.6 & 6.1 & 15.2 \\
\hline Total & 3879 & 0.6 & 2.2 & 2.8 & 0.8 & 0.6 & 1.5 & 2.1 & 0.9 & 3.0 & 4.0 & 9.7 \\
\hline
\end{tabular}

Source: Authors' calculation. 
Figure 7: Change in Exports by Region

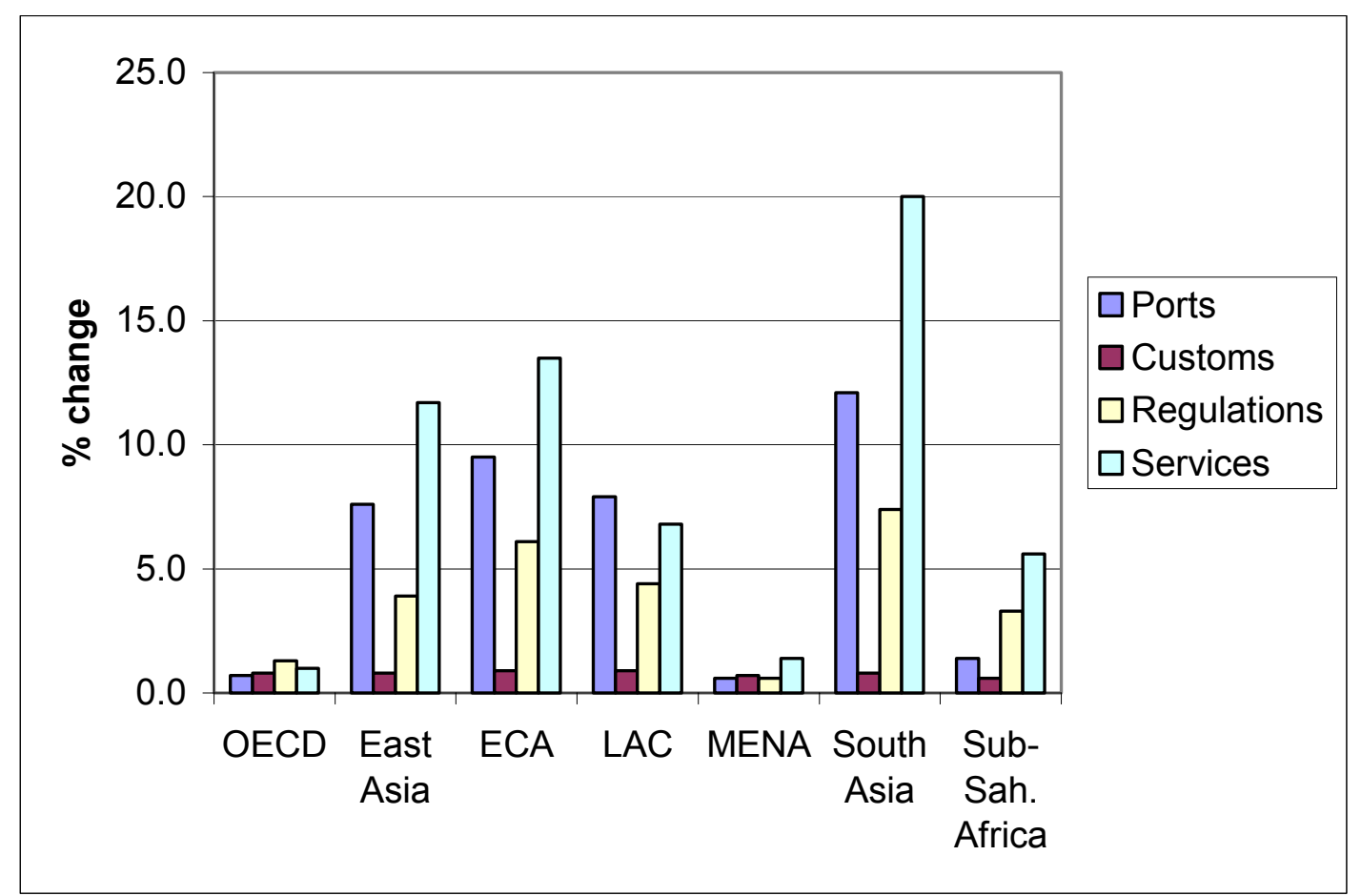

Source: Authors' calculation.

Figure 8: Change in Imports by Region

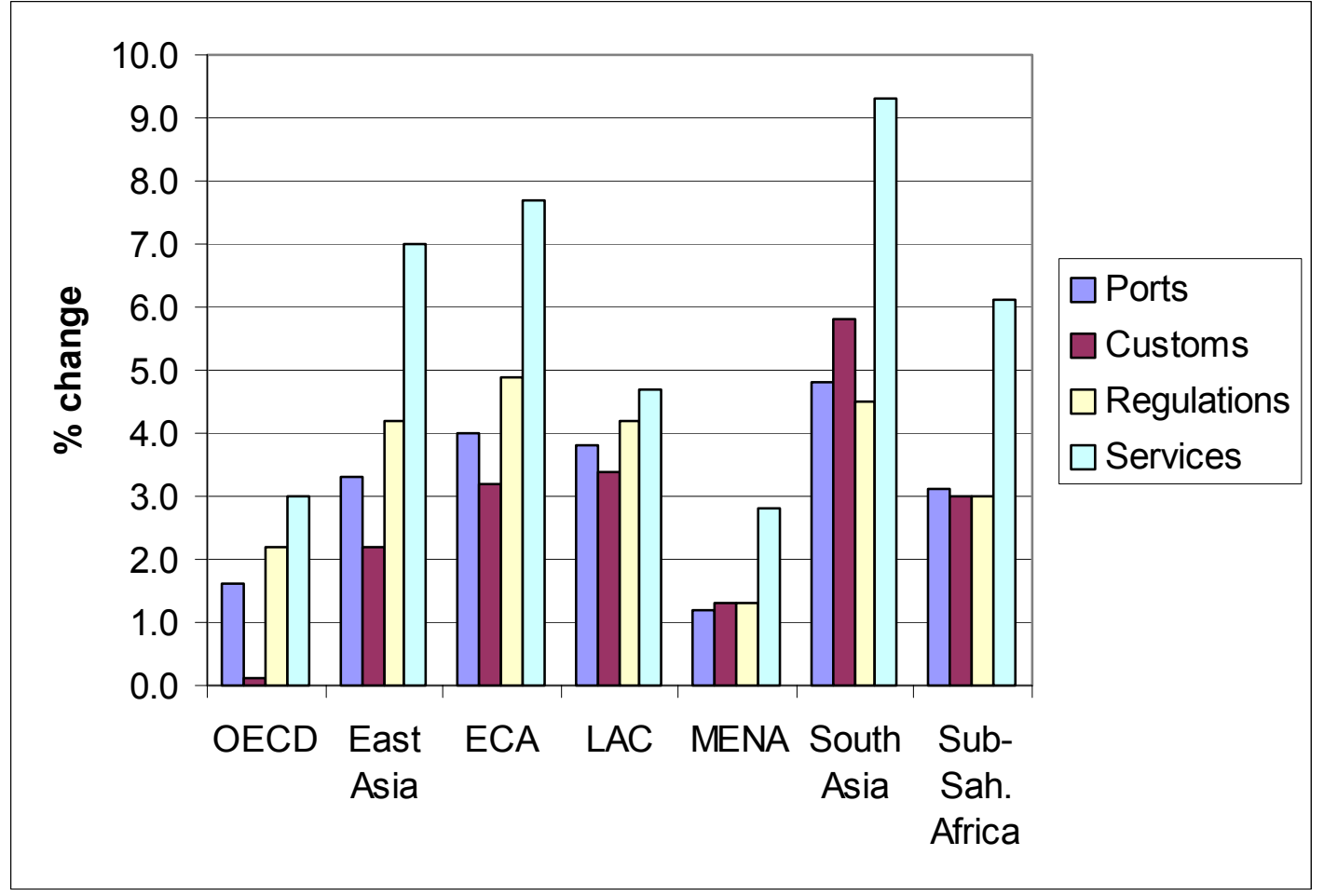

Source: Authors' calculation. 
Figure 9: Change in Manufacturing Exports 'Half-way to the Global Average' Scenario: Gains from Domestic and Partners' Reform

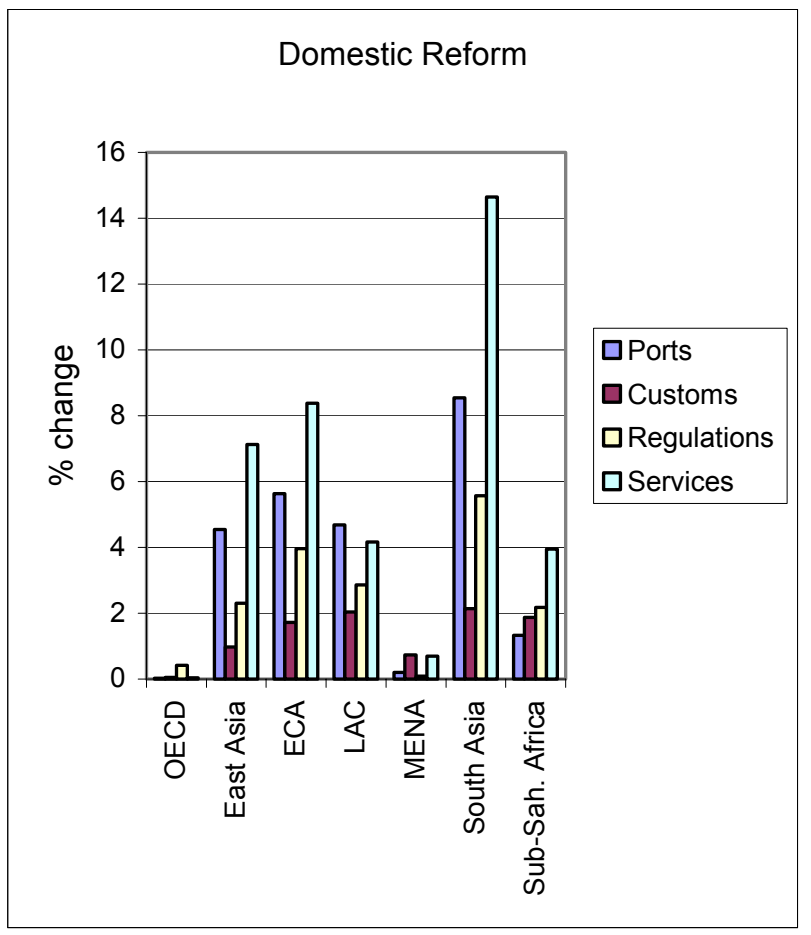

Source: Authors' calculation.

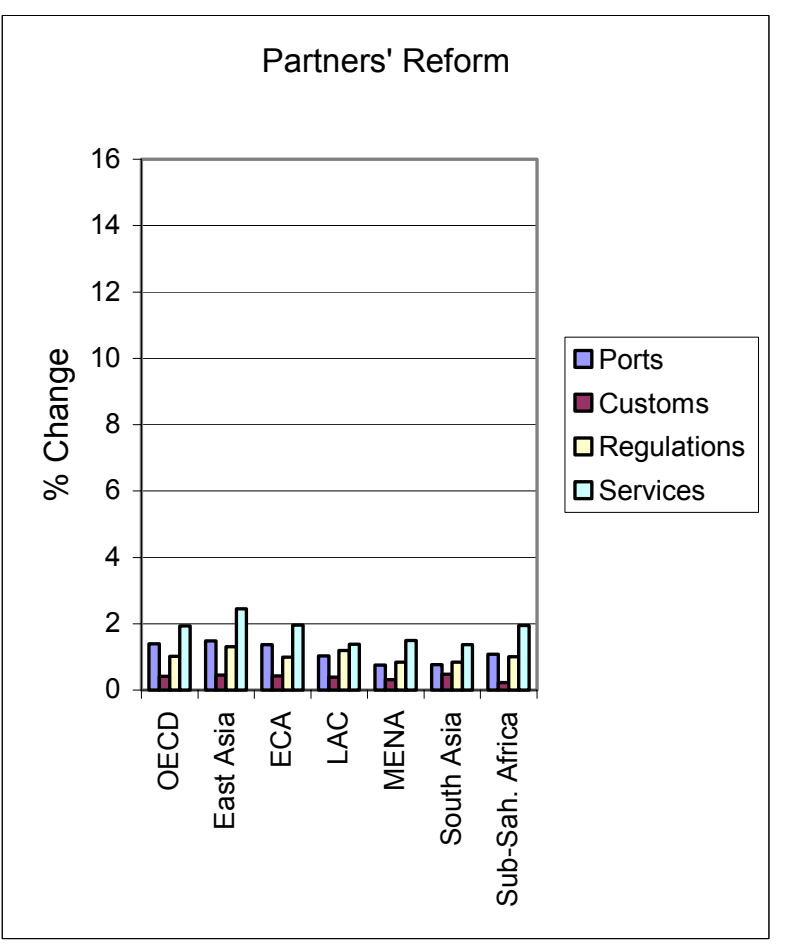

Source: Authors' calculation.

Figure 10: Trade Gains from Domestic and Partners' Reform: Country Examples

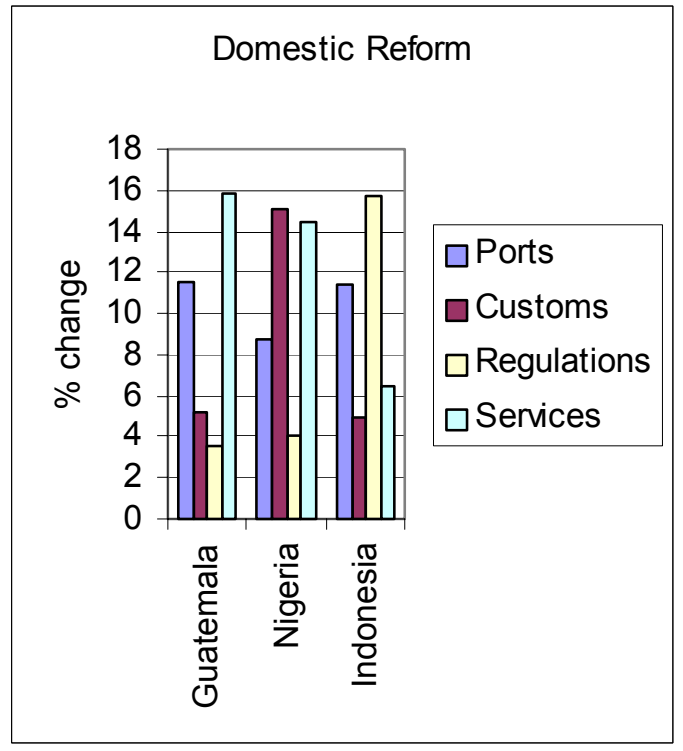

Source: Authors' calculation.

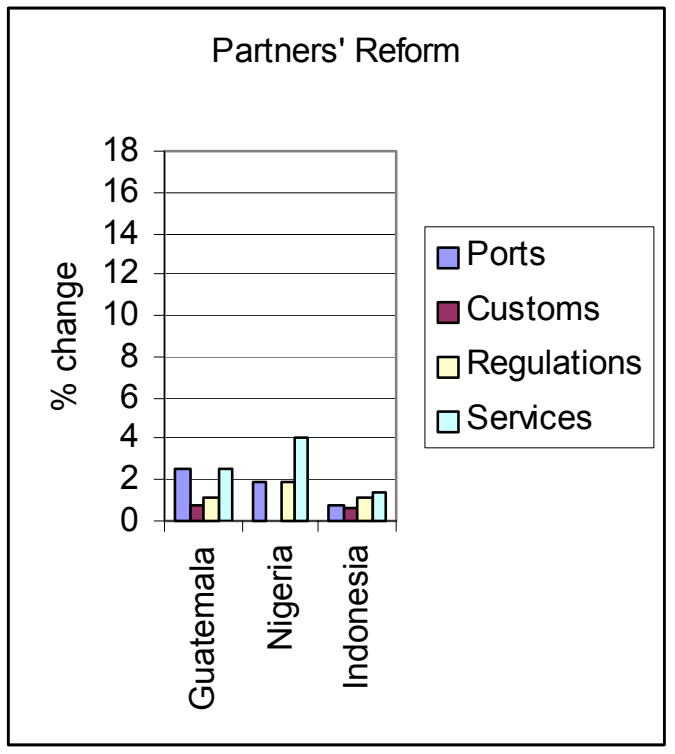

Source: Authors' calculation. 